تأثير تمرين تناوبى با شدت زياد و حجم كم بر محتواى ساركولمايى ناقلهاى اسيد جرب (FABP FAT/CD36 و

$$
\begin{aligned}
& \text { (FABPpm در مردان جوان }
\end{aligned}
$$

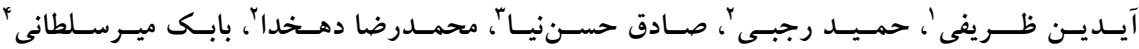

$$
\begin{aligned}
& \text { 1- دانشجوى دكترى فيزيولوزى ورزشى دانشكده تربيت بدنى دانشكاه خوارزمى دئس }
\end{aligned}
$$

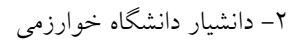

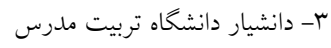

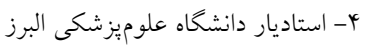

\begin{tabular}{|c|}
\hline 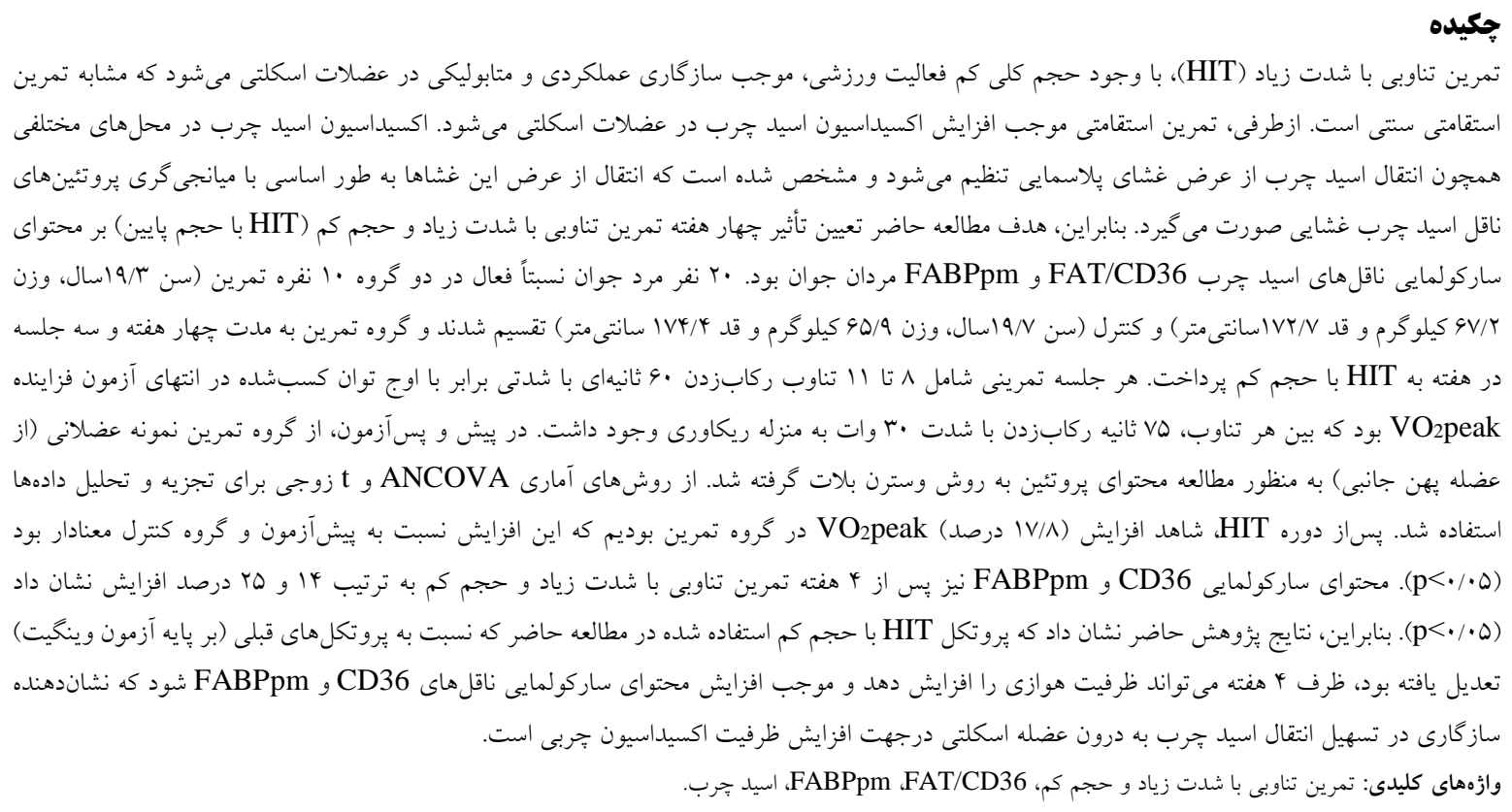 \\
\hline
\end{tabular}

\title{
The Effect of Low Volume High Intensity Interval Training on Sarcolemmal Content of Fatty Acid Transport Proteins (FAT/CD36 and FABPpm) in Young Men
}

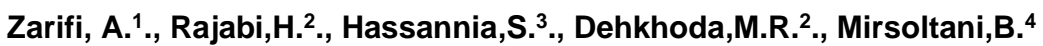 \\ 1- Exercise physiology Ph.D student, Kharazmi University \\ 2- Kharazmi University \\ 3- Tarbiat Modares University \\ 4- Alborz University of Medical Sciences
}

\begin{abstract}
High-intensity interval training (HIT) induces skeletal muscle metabolic and performance adaptations that resemble traditional endurance training despite a low total exercise volume. On the other hand, fatty acid oxidation is increases in skeletal muscle with endurance training. This process is regulated in several sites, including the transport of fatty acids across the plasma membrane. The transportation across this membrane is recognized to be primarily protein mediated. Therefore, the purpose of this study was to determine the effect of low-volume high intensity interval training on protein content of sarcolemmal fatty acids transporters (FAT/CD36 and FABPpm) in young men. Twenty recreationally active young men were assigned to a HIT ( $\mathrm{n}=10,19.3 \mathrm{yr}$ old, $67.2 \mathrm{~kg}$ body wt, and $172.7 \mathrm{~cm} \mathrm{ht}$ ) or Control ( $\mathrm{n}=10,19.7 \mathrm{yr}$ old, $65.9 \mathrm{~kg}$ body wt, and $174.4 \mathrm{~cm}$ ht) group. HIT group performed three training sessions per week over 4 weeks. Each session consisted of $8-11 \times 60 \mathrm{~s}$ intervals at $\sim 100 \%$ of peak power output elicited during a ramp VO2peak test separated by $75 \mathrm{~s}$ of recovery. Skeletal muscle (vastus lateralis) biopsy samples were obtained before and after training. HIT increased (17.5\%)
\end{abstract}


$\mathrm{VO}_{2}$ peak $(\mathrm{p}<0.05)$. Also, after 4 weeks low-volume HIT, sarcolemmal content of CD36 and FABPpm increased 14 and 25 percent, respectively $(p<0.05)$. Therefore, the results showed that the practical model of low-volume HIT could increase aerobic capacity and sarcolemmal content of CD36 and FABPpm. The increase indicates that the facilitation of in muscle fatty acid transportation can be adapted which in turn increases the fat oxidation capacity.

Keywords: Low-volume High-Intensity Interval Training, FAT/CD36, FABPpm, Fatty acid.

مقدمه

اسيدهاى جرب در بسيارى از فر آيندهاى سلولى همجيون سنتز غشا و مسير سيخنالى درونسلولى و تنظيم رونويسى مشاركت مى كنند و منبع بارزش انرزى در هنگام فعاليت ورزشى در شدت هاى يايين تا متوسط قلمداد مىشوند (D9). از طرف ديخر، تجمع اسيدهاى جرب و افزايش تجربى بدن در اثر بىتحركى، كه در سبك زندكى امروزى تهى

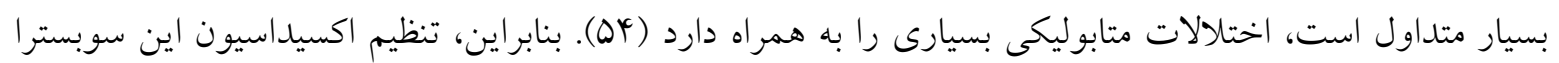
بهويزه در بافتهاى فعال مانند عضلات اسكلتى در سلامت انسان نقش كليدى دارد. فرآيندهاى تنظيمى بسيارى در اكسيداسيون اسيد جرب دره عضلات اسكلتى صورت مى گيرد. از آن جمله مىتوان به انتقال اين سوبسترا به درون سلول عضلانى اشاره كرد؛ زيرا سهم زيادى از اسيد جرب اكسيدشده از اسيدهاى جرب استريفيهنشده (NEFAs) 'يلاسمايى فراهم مى شود (O9). مشخص شده است كه هم انتشار غيرفعال ؟و هم

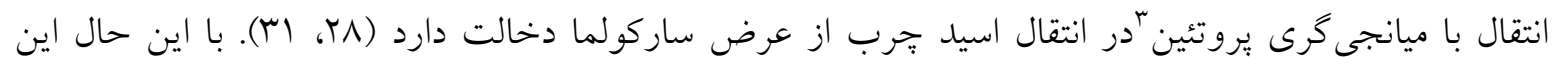
ناقل هاى يروتئينى همانند انتقالدهندههاى مرسوم كه يك روزنه يا كانال ايجاد مي كنند عمل نمى كنند (YY) و احتمالاً مراحل مختلف انتقال اسيد جرب را تسهيل مى كنند. تاكنون سه نوع يروتئين در انتقال غشاى پِاسمايى اسيد جرب

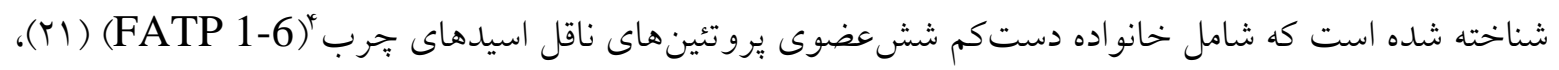

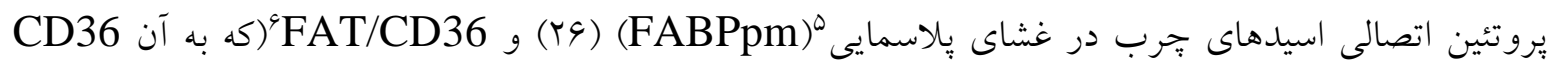
نيز اطلاق مى شود) است (Y). اين بروتئين هاى ناقل تأثيرات متفاوتى بر انتقال اسيد خرب إن ساركولما نشان مى دهند،

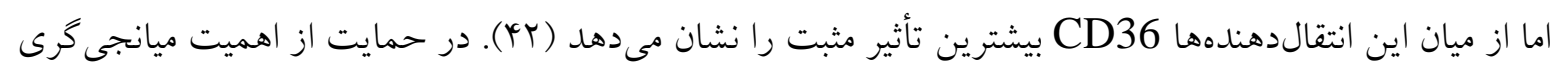

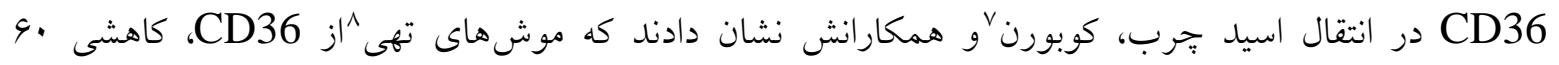
درصدى در انتقال اسيد جرب به درون بافت جربى، قلب و عضلات اسكلتى قرمز ظاهر كردند (IV) و توانايى اجراى فعاليت ورزشى استقامتى در آنها كاهش يافت؛ در حالى كه در موشهاى بيشبيانُُهده CD36، توانايى اجراى فعاليت ورزشى افزايش يافت (1). همجنين، تعدادى از تحقيقات با استفاده از مدلهاى مختلف همجيون

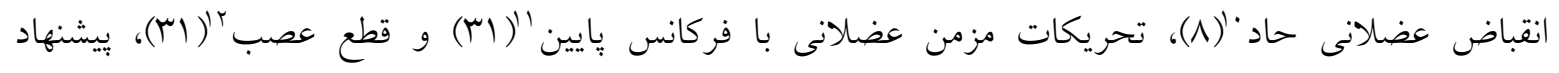

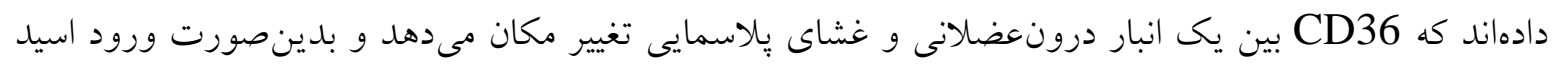

1. Nonesterified fatty acids

2 Passive diffusion

3 Protein-mediated transport

4 Fatty acid transport proteins

5 Plasma membrane fatty acid -

binding protein
6 Fatty acid translocase/Cluster of Differentiation 36

7. Coburn

8 Null

9. Over expressing

1.0Acute
1. IChronic low-frequency muscle stimulation

1.Denervation 
جرب به سلولهاى عضلانى را تنظيم مى كند (9) و يروتئينى مهم در سازكارى ناشى از تمرين در اكسيداسيون اسيد

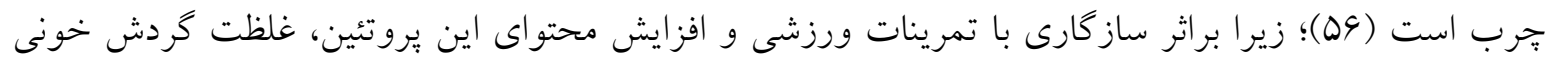
اسيدهاى خرب افزايش نمى يابد. مطالعات درباره سلولهاى عضله اسكلتى و قلبى نشان داد كه با استفاده از از

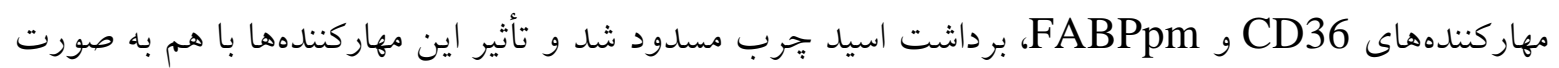

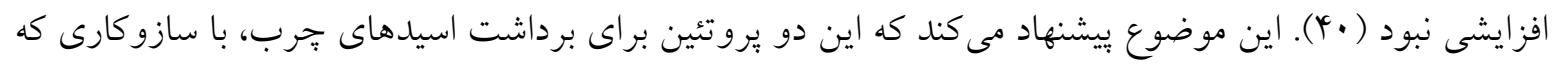

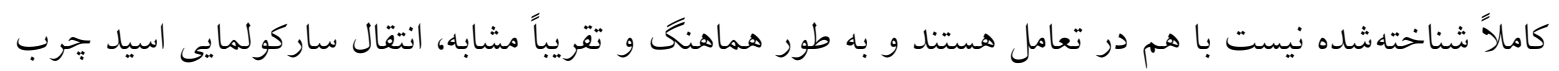

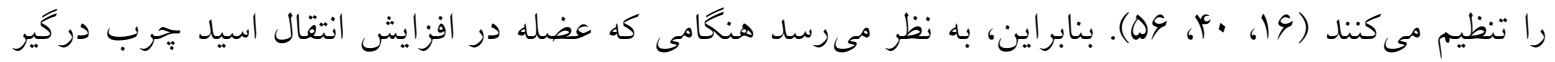
است، بايستى اين دو يروتئين با هم تحت مطالعه قرار بخيرند.

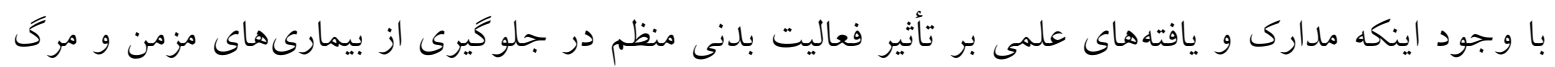

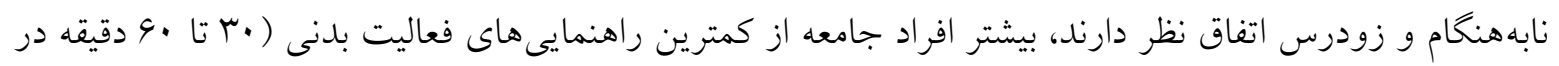

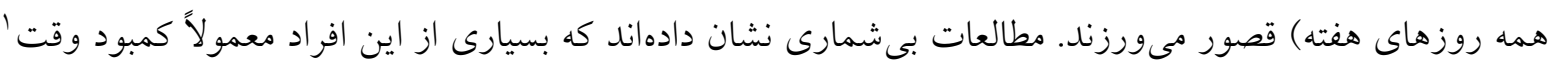

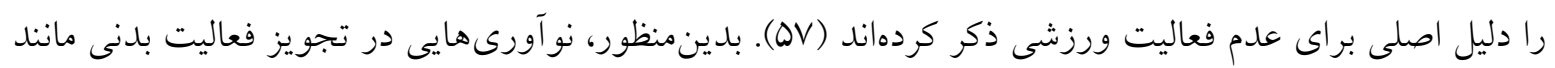

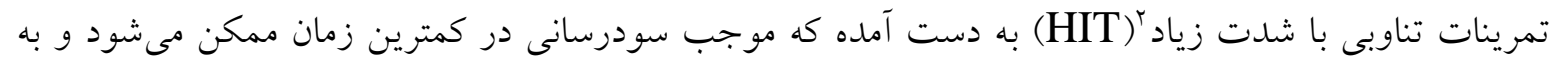
نظر مىرسد مى تواند دستاوردهاى بارزشى در افزايش سطوح فعاليت و سلامت افراد جامعه داشته باشد. امروزه ارزش بالقوه تمرين شديد تناوبى در زمينه توسعه سلامت و آمادكى، حتى در افرادى كه بيمارىهاى كوناكونى

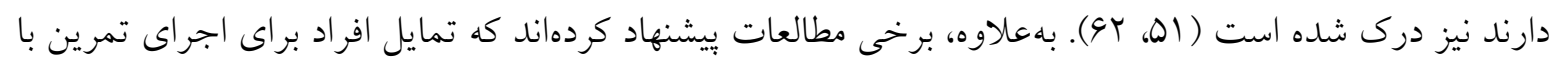
تكرار كم و شدت زياد، بيشتر از برنامه تمرينى با تكرار زياد و شدت كم است (•r) و حتى درك لذت بـت بيشترى نيز

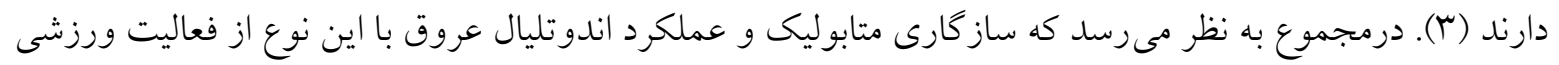
مى تواند با وساطت مسير سيخنالى سلولى صورت گيرد كه حتى در كوتاهمدت به ساز كارى مشابه با ساز كارى با باريا

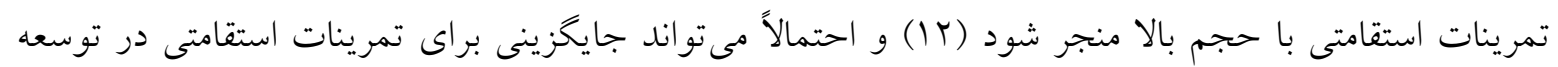
سلامت متابوليك و كاهش بيمارىهاى مزمن باشد.

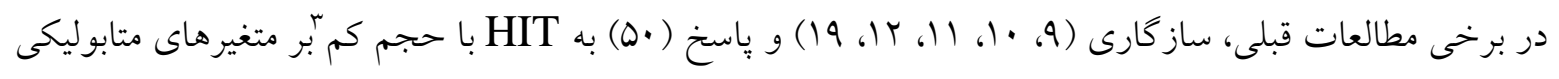

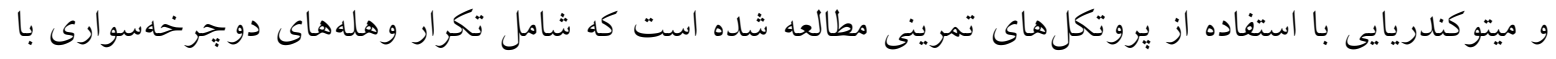

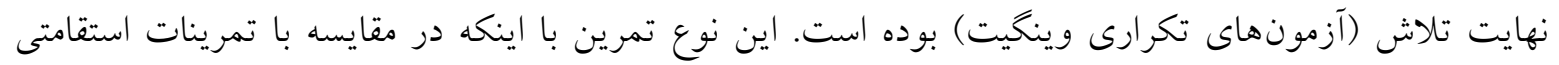

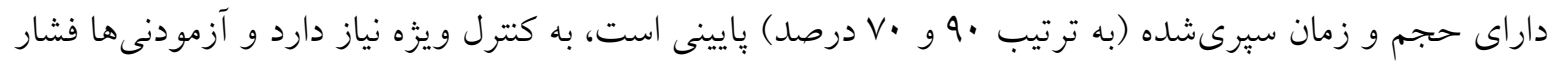

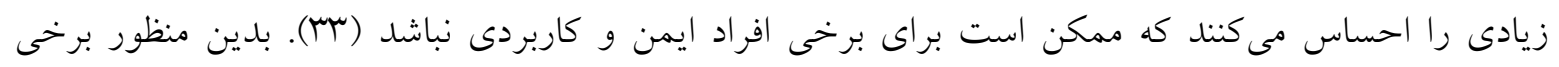

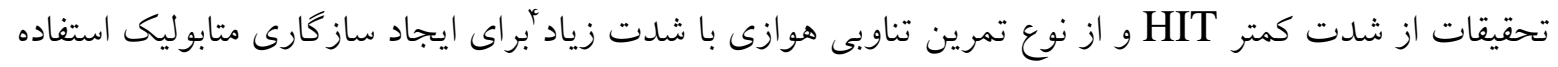




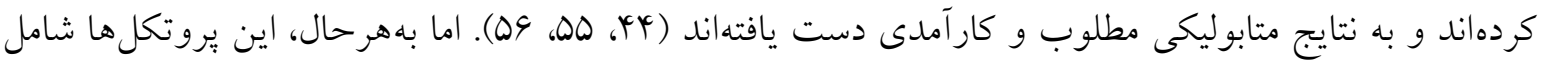
جلسات تمرينى تناوبى با مدتزمانى در حدود ·9 دقيقه بودهاند و به نظر نمىرسد بتوانند مشكل اساسى كمبود

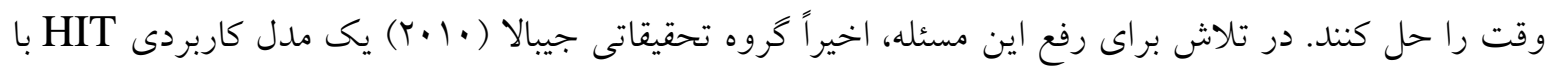
حجم كم را بيشنهاد كردهاند كه در آن شدت مطلق تناوبها نسبت به مطالعات قبلى HIT با حجم كم، كاهش و و مدت تناوب ها افزايش يافت، همجنين دوره ريكاورى بين تناوبها كاهش يافت؛ به كونهاى كه به طور نسبى ازلحاظ زمان كارآمد بود و در آن فقط در حدود ·ل تا ها دان دقيقه فعاليت ورزشى انجام مى شد و هر جلسه تمرين دوره

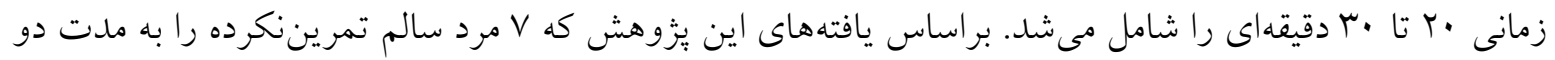

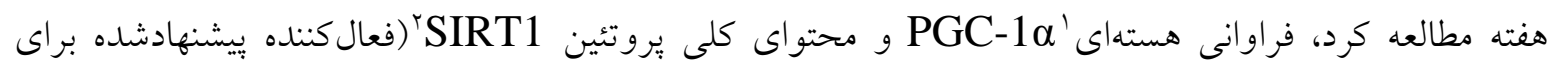
و بيوزنز ميتو كندرى) افزايش يافت. همجنين تمرين موجب افزايش كليكوزن استراحتى عضله و محتواى كلى يروتئين GLUT4 شد و عملكرد فعاليت هوازى و بى هوازى بهبود بيدا كرد (سب). بنابراين، ازآنجاكه تغيير در بيان و محتواى PGC-1 به منزله كليد اصلى |فزايش بيوزنز ميتوكندريايى در اثر فعاليت بدنى، مىتواند همزمان با توسعه اكسيداسيون جربى بدن همراه باشد (سT)، به نظر مىرسد يروتكل تمرينى مشابه نيز مىتواند موجب ساز گارى مثبت در سوخت خربى در عضلات بدن شود و اين ساز گارى براى افراد در تلاش براى كاهش

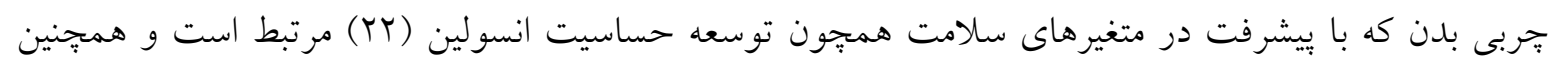
براى ورزشكاران در تلاش براى ذخيرهسازى كربوهيدرات طى رقابتهاى ورزشى، اهميت درخور توجهى دارد. از طرف ديخر، به دليل اينكه جزخونكى تنظيم ورود اسيد جرب به به درون سلولهاى عضلانى نقش كليدى در اكسيداسيون آن دارد و ديده شده است كه اكثر اين ورود، به يروتئينهاى ميانجى بهخصوص CD36 وابسته است (Y (Y)، اين سؤال بيش آمد كه در اثر جهار هفته HIT با حجم كم، آيا تغييرى در محتواى ساركولمايى بروتئينهاى ناقل CD36 و FABPpm به وجود مي آيد؟

\section{روش}

يُزوهش حاضر به روش شبهتجربى با طرح ييش و يس آزمون و به صورت تكى گروهى انجام شد. با اين حال براى

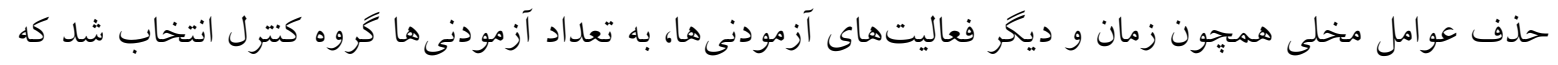
فقط در آزمون VO2peak مشاركت داشتند و نمونهبردارى عضلانى (به دليل ملاحظات اخلاقى) از اين خروه

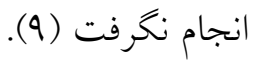
آزمودنىها: نمونه اين يزوهش شامل ·ل نفر مرد جوان در گروه تمرين و • ا نفر مرد جوان در گروه كنترل بود (جدول (). اين تعداد نمونه، با توجه به تعداد نمونها در مقالات مرتبط تعيين شد (م9). آزمودنىهاى مطالعه را 
مردان جوان در سن دانشخاه تشكيل دادند كه سبك زندگى نسبتاً فعالى داشتند. اين افراد از ميان داوطلبانى كه براى مشاركت در يزوهش اعلام آمادگى كرده بودند، با درنظر كرفتن سوابق سلامت و فعاليت بدنى (ازطريق مصاحبه) و و همخنبودن سبك زندىى (زندگى در خوابخاه دانشجويى و استفاده از غذاى دانشخاه) انتخاب شدند.

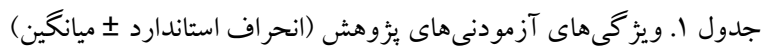

\begin{tabular}{|c|c|c|c|c|}
\hline \multicolumn{2}{|c|}{ وزن (kg) } & \multirow{2}{*}{ قد (cm) } & \multirow{2}{*}{ سن (سال) } & \multirow{2}{*}{ كروه } \\
\hline يس آزمون & ييش آزمون & & & \\
\hline $9 \Delta / V \pm \Delta / \Delta D$ & $90 / 9 \pm 0 / 90$ & $\mid V V^{E} / Y^{\leftarrow} \pm N /$ & $19 / \mathrm{V} \pm \cdot / 9 \mathrm{~V}$ & كنترل (•ln=1) \\
\hline $9 V / 4 \pm 9 / 9 T$ & $G V / T \pm 9 / V T$ & IVT/V $\pm \Lambda / 4 \varphi$ & $19 / \Gamma \pm \cdot / 4 \Lambda$ & تمرين (·+lne \\
\hline
\end{tabular}

بس از آشنايى كامل با روند يزوهش و احتمال وقوع عوارض جانبى (درقالب كاركاه آموزشى و نمايش فيلم) و با

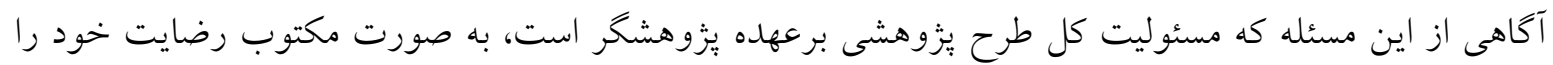
مبنى بر مشاركت در تحقفيق اعلام كردند.

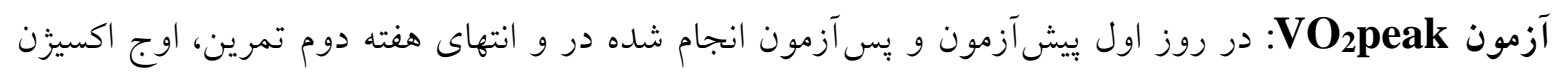

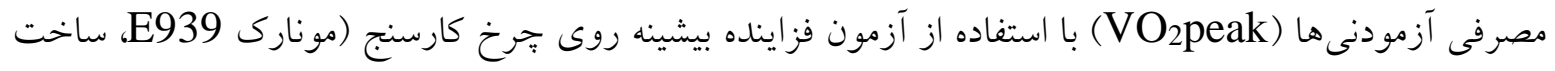

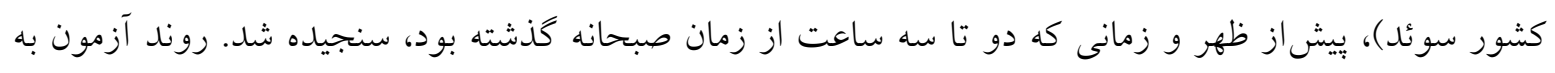

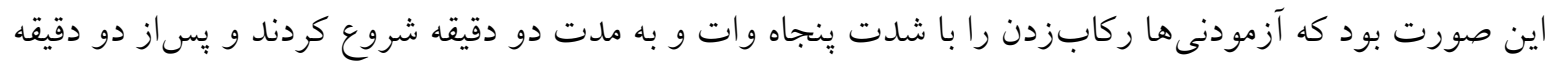

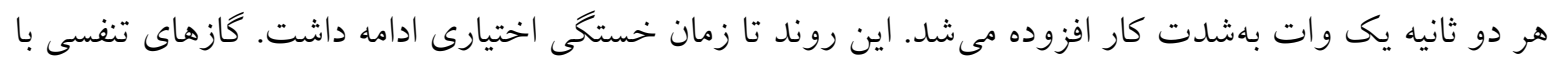

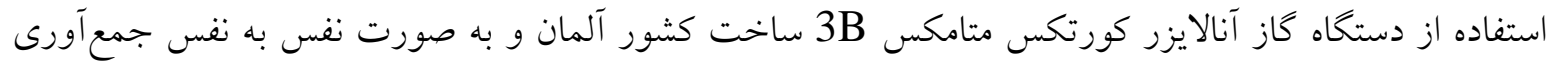

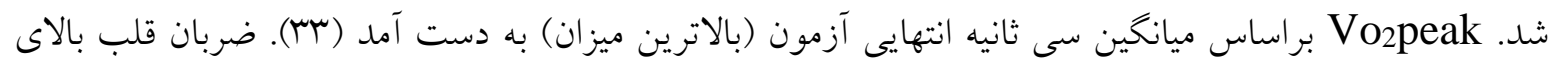

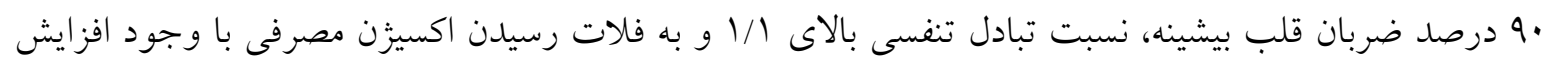
شدت تمرين از نشانهاى صحت نتيجه و رسيدن به VO2peak و توقف آزمون (رسيدن به حداقل دو مورد از سه ملاك) بود. نمونهبردارى عضلانى: در حدود ^^ ساعت پِّاز آزمون VO2peak، آزمودنى ها به دنبال صرف وعده صبحانه

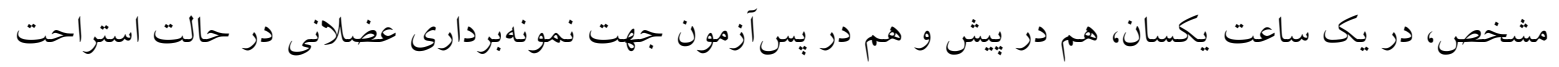

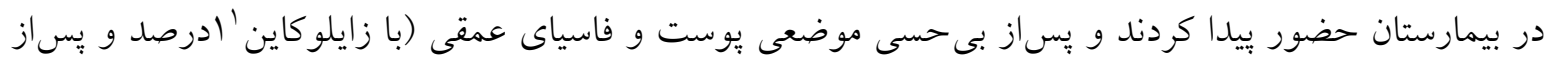

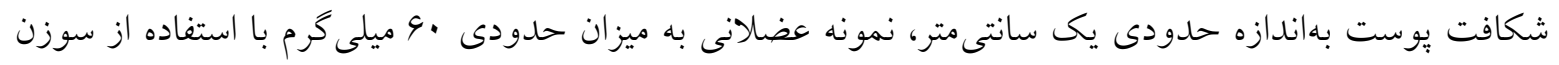


نمونهبردارى (سوزن Abrams Luer Lock با قطر جهار ميلىمتر، ساخت شركت Unimed كشور سوئيس) از عضله يهن جانبى اكرفته شد و يساز دوبار شستوشو با سرم نرمال سالين به منظور حذف خون از بافت، بلافاصله در تانك حاوى محلول نيتروزن مايع قرار گرفت و براى تجزيه و تحليل بعدى به دماى •^- درجه سانتى گراد منتقل

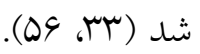
كَفتنى كه مجوز قانونى اجراى نمونهبردارى عضلانى از طرف شوراى يزوهشى دانشخاه علوميزشكى البرز، پِيساز

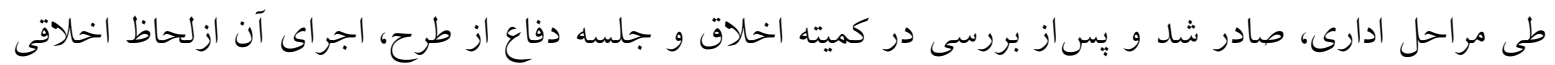
تأييد و تصويب كرديد.

كنترل تغذيه: براى به حداقلر ساندن تأثير تنوع رزيم غذايى بر متغيرهاى يزوهش، از آزمودنىها خواسته شد رب سـاعت قبلاز اجراى آزمونها از مصـرف كافئين، الكل و دخانيات و هر كونه فعاليت بدنى شـديد يا طولانىمدت خوددارى كنند، و بآ ساعت قبل از هر آزمون ميزان، نوع و زمان مصرف مواد غذايى و فعاليتهاى روزمره و زمان خواب را در فرم مخصوص به دقت ثبت كنند. كيى اين فرمها در يس آزمون در اختيار آزمودنىها قرار كرفت و از

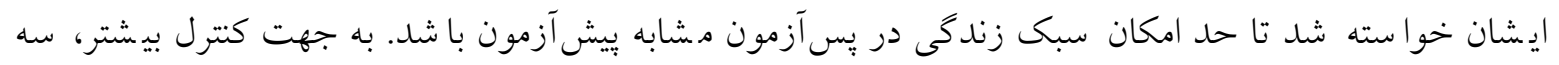

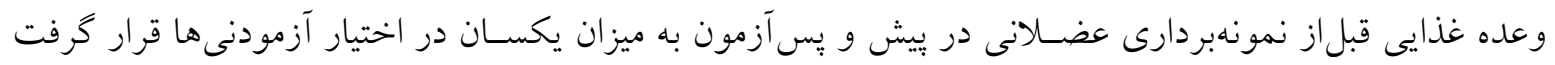

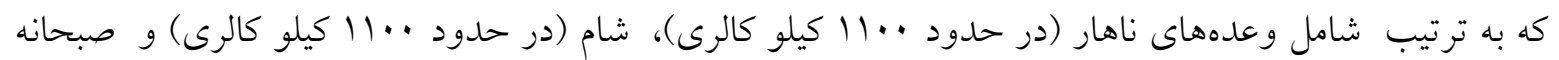
(در حدود ... مه كيلو كالرى) بود.

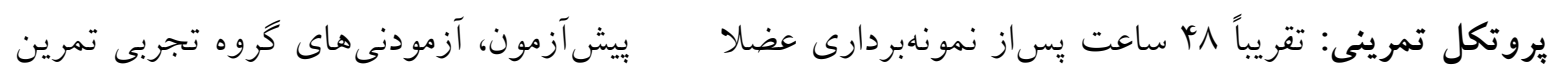
را در سه جلسه در هفته و به مدت جهار هفته شروع كردند. هر جلسه تمرينى شامل هشت تا يازده تكرار ركابزدن شصت ثانيهاى با شدتى برابر با اوج توان كسبشده در انتهاى آزمون فزاينده VO2peak (شش جلسه تمرين اول براساس Pax ب بيش آزمون و با هشت و ده تكرار و شش جلسه تمرين دوم براساس Pax آزمون ميانى و با يازده تكرار شصت ثانيهاى) بود كه بين هر تكرار، VD ثانيه ركابزدن با شدت •r وات بهعنوان ريكاورى وجود داشت (سب). كفتنى است كه اجرايىبودن اين تمرين و نحوه برنامهريزى در تعداد تناوبهاو و نحوه اعمال اضافهبار، دوماه قبل از شروع اجر ایى يزوهش در مطالعهاى راهنما (Pilot study) تحت بررسى قرار كرفت.

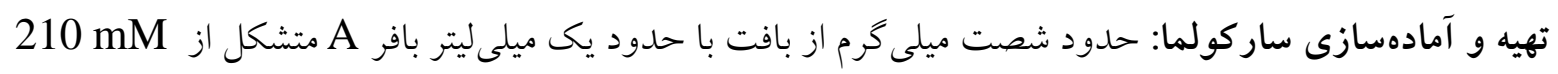

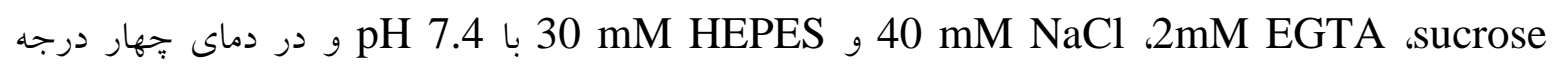

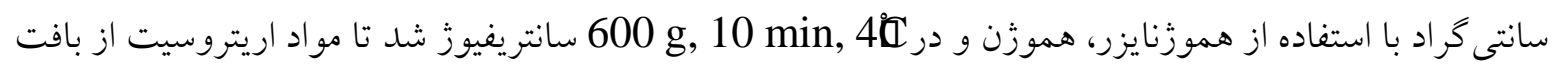

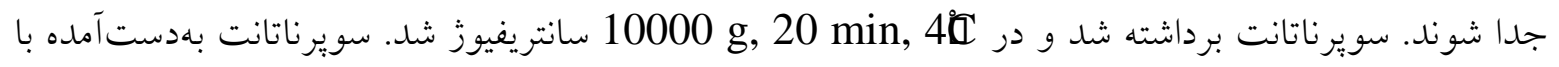

1 Vastus lateralis 


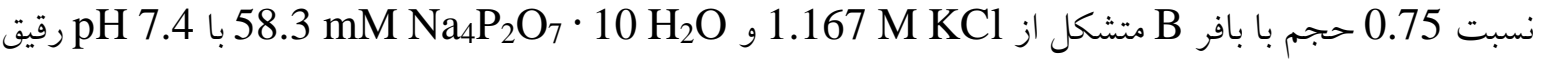

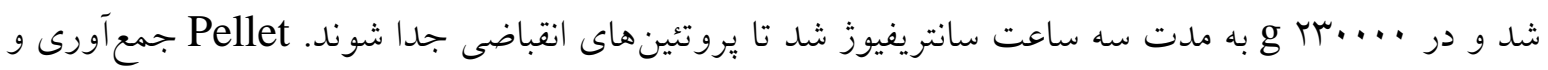

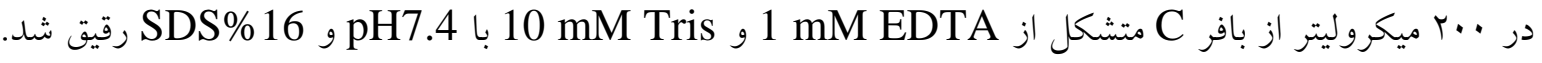

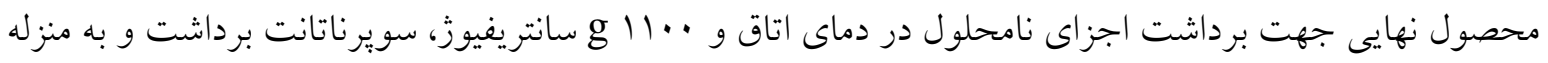

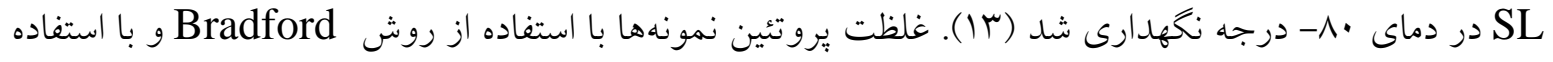

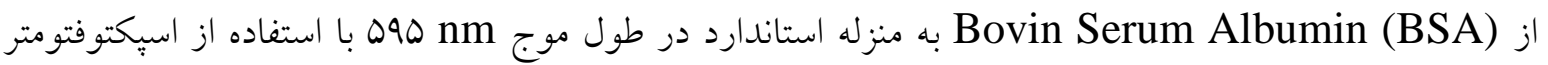

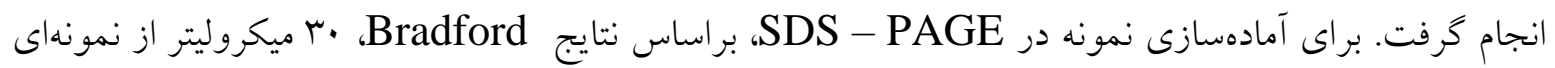
كه كمترين غلظت را داشت برداشته شد و نمونههاى ديخر نيز براساس آن رقيق شدند (ميزان نمونه انتخابشده

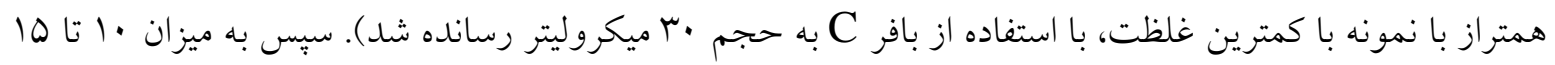

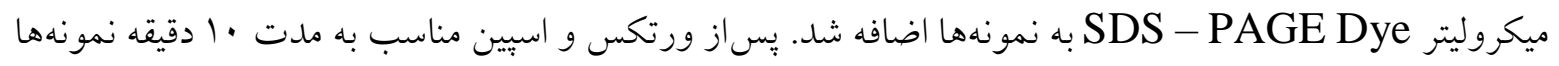

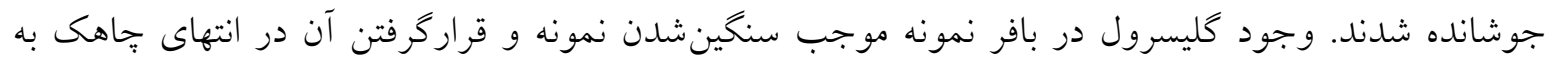

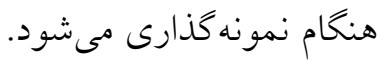

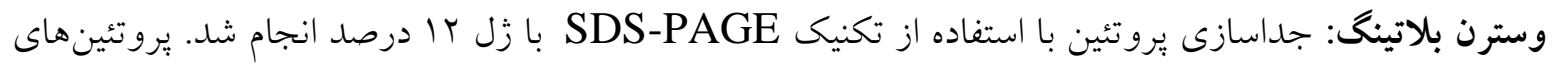

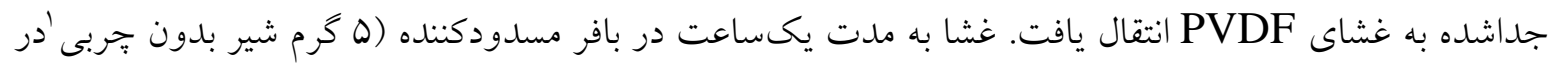

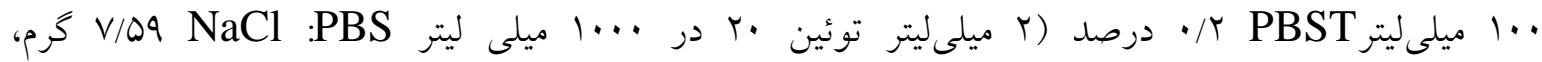

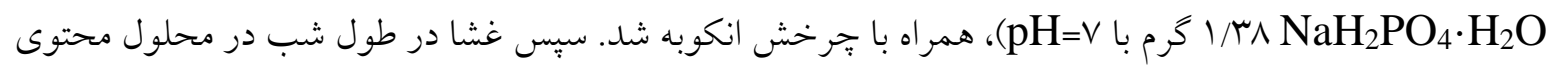

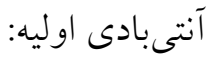

CD36 monoclonal antibody, clone FA6.152, Catalogue Number: MAB4662, host: Mouse, reactivity: Human, Quantity: $200 \mu \mathrm{g}$, Company: Abnova GOT2 polyclonal antibody (A01), Catalogue Number: H00002806-A01, host: Mouse, reactivity: Human, Mouse, Rat, Quantity: $50 \mu \mathrm{g}$, Company: Abnova با غلظت micrograms/ml 2 كه در بافر مسدودكننده رقيق شده بود قرار كرفت. بِساز سه مرحله شستوشو با محلول PBST، غشا به مدت يكساعت در دماى اتاق درمعرض آنتىبادى ثانويه ضد موشى (HRP) قرار

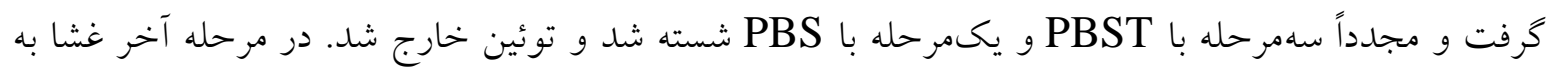

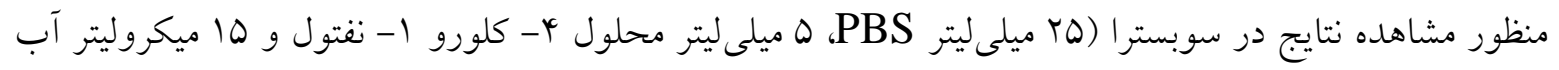
اكسيزنه) قرار گرفت. بهمض ظاهرشدن باندها (به رنخ طوسى تيره)، غشا به آب مقطر منتقل شد تا بِ بسزمينه

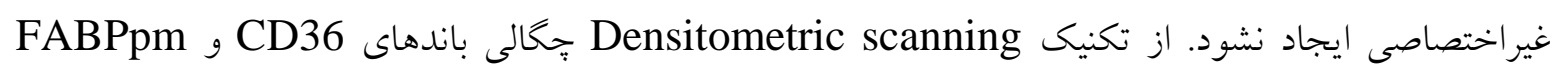
تعيين شد

1Skim milk 
تجزيه و تحليل آمارى: يساز تعيين نرمالبودن توزيع دادهها ازطريق آزمون كلومو گروف - اسميرنف، براى مقايسه

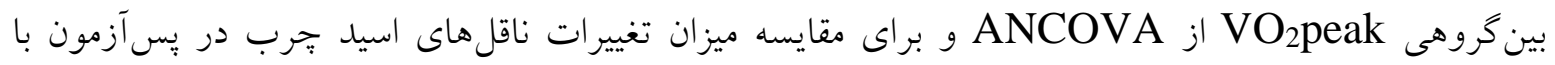

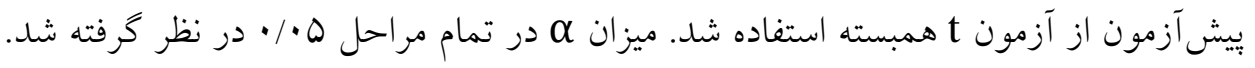

يافتهها

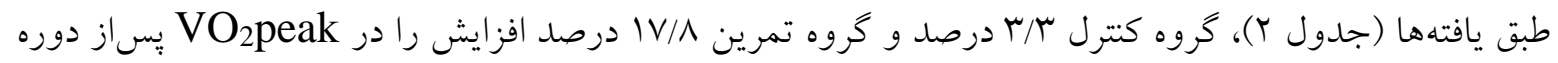

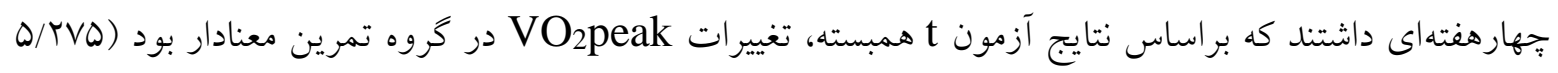
ل

$$
\text { كروه كنترل و تمرين مشاهده شد ( }
$$

جدول r. تو صيف مقادير و مقايسه بين گروهى RER و RO و ضربان قلب در VO peak

\begin{tabular}{|c|c|c|c|c|c|}
\hline ميزان p p & ميزان F F & بِس آزمون & يبش آزمون & كروه & متغير \\
\hline \multirow{2}{*}{$\cdot / \cdot \cdot 1$} & \multirow{2}{*}{$10 / 4 \cdot 4$} & ${ }^{*} r / 4 \pm \cdot / 41$ & $r / q \pm \cdot / r \Delta$ & تمرين & \multirow{2}{*}{$\begin{array}{c}\mathrm{VO}_{2} \text { peak } \\
1 / \text { min }\end{array}$} \\
\hline & & $\Gamma / \Lambda \pm \cdot / \mu$ & $r / V \pm \cdot / T \&$ & كترل & \\
\hline \multirow{2}{*}{$\cdot / 9 \wedge \Delta$} & \multirow{2}{*}{$\cdot \ldots r$} & $1 / \pi \pm \cdot / 1$ & $1 / \Gamma \pm \cdot / \cdot 9$ & تمرين & \multirow{2}{*}{ RER } \\
\hline & & $1 / r \pm \cdot / \cdot \Delta$ & $1 / r \pm \cdot / \cdot 0$ & كنترل & \\
\hline \multirow{2}{*}{$\cdot / r \cdot 9$} & \multirow{2}{*}{$1 / N \pi T$} & $19 \cdot / \cdot \pm r / F V$ & $M N V / r \pm Y / \cdot r$ & تمرين & \multirow{2}{*}{$\begin{array}{c}\mathrm{HR} \\
\text { beats/min }\end{array}$} \\
\hline & & $\mid \wedge q / 1 \pm 9 / 4 \wedge$ & $\mid \Lambda N / Q \pm r / \Lambda V$ & كنترل & \\
\hline
\end{tabular}

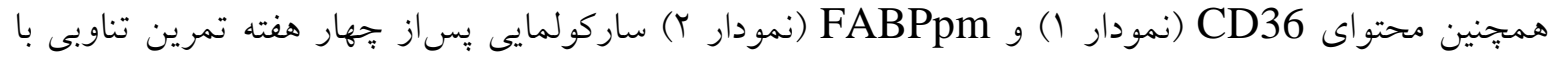
شدت بالا و حجم هايين به ترتيب در حدود كا او هو درصد افزايش داشت كه اين تغييرات معنادار بود (CD36)

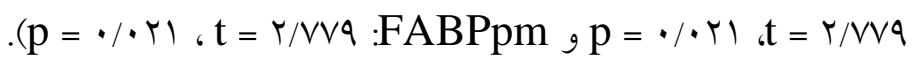




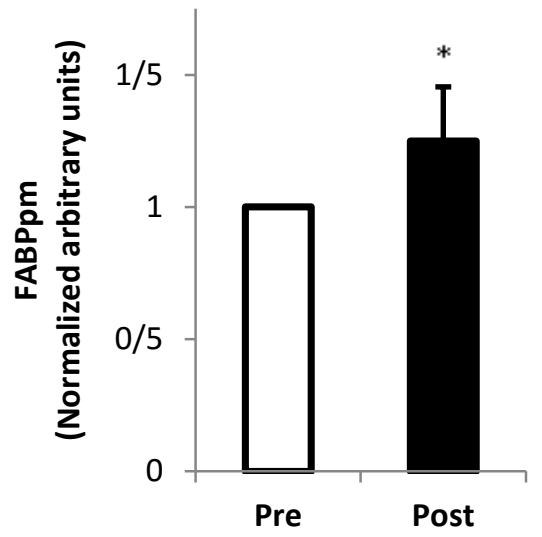

نمودار r. توصيف محتواى FABPpm ساركولمايى قبل و

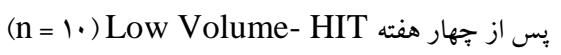

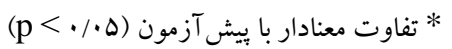

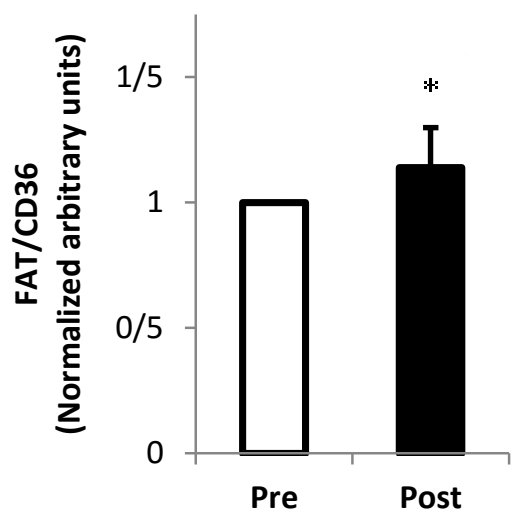

نمودار ا. توصيف محتواى FAT/CD36 سار كولمايى قبل و يس از جهار هفته

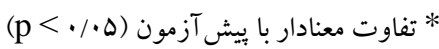

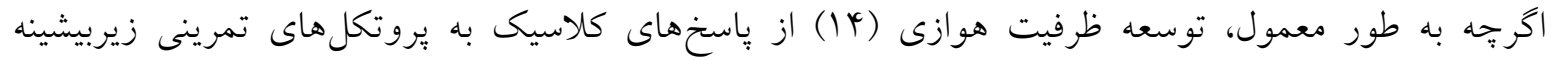

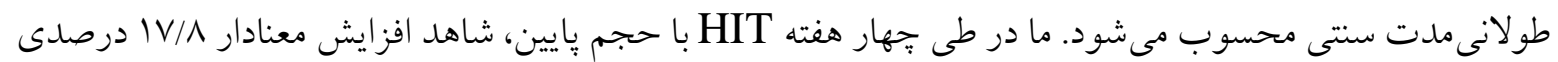

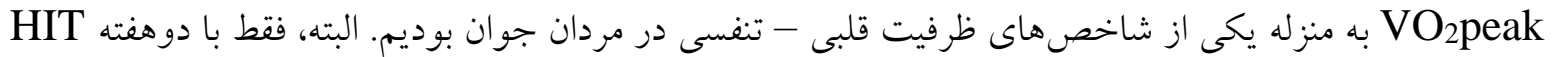

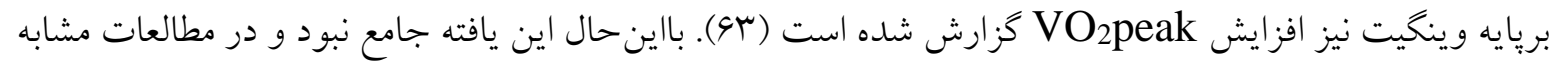

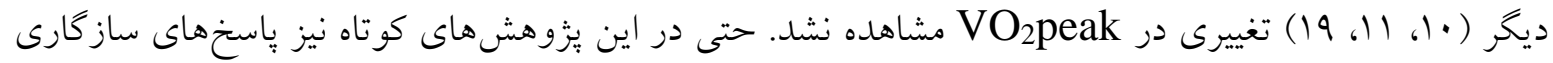
جالب توجهى به دست آمد و افزايش معنادارى در عملكرد ورزشى، فعاليت آنزيم سيترات سيتتاز عضله اسكلتى و محتواى يروتئين سيتوكروم اكسيداز C مشاهده شد، ولى به دليل كو تاهبودن دوره تمرين تغيير محسوسى در فعاليت

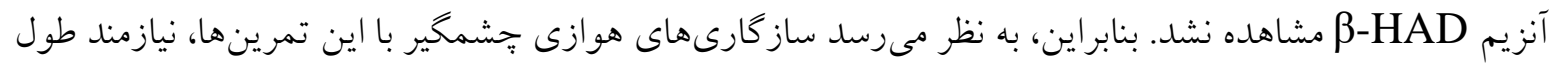

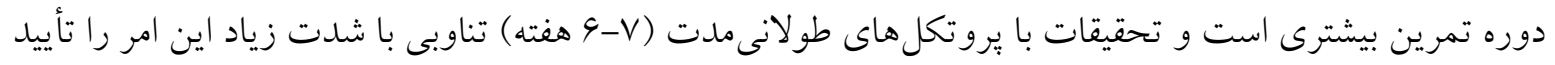

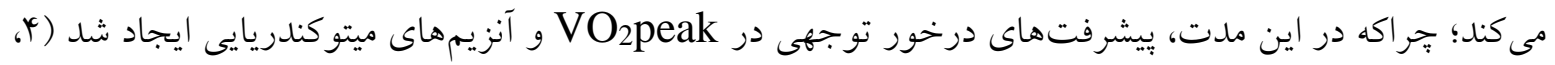

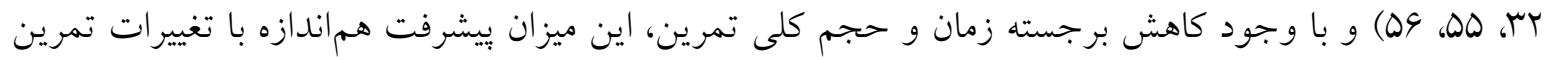
استقامتى سنتى بود (YI). هم:جنين با كاهش شدت تمرين و انجام تناوبهاى تمرين با شدتى بين مدل تمرينى زيربيشينه كلاسيك و سرعتى (در حدود •9 درصد VO

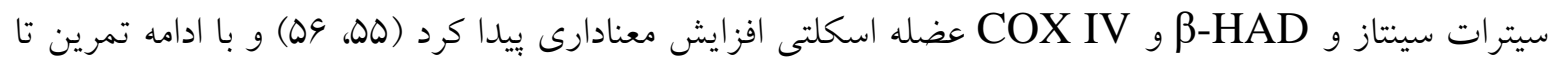

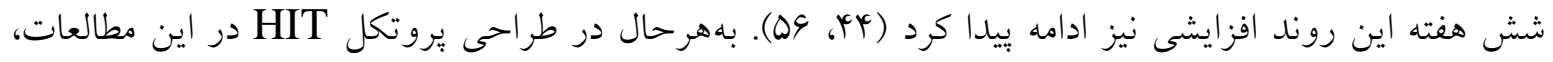

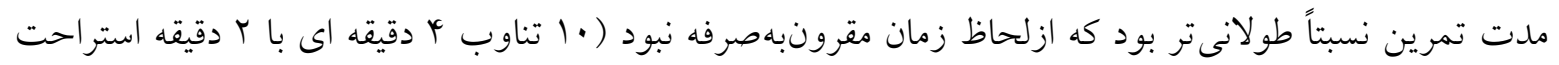


بين تناوبها) و به اين ايده اعتقاد داشتند كه در تمرين تناوبى، افزايش VO2peak نيازمند مقدار ويزهاى از حجم فعاليت ورزشى است، اما هنوز اين سؤال مطرح بود كه دستكم اين حجم ويزه در HIT براى بهبود توان هوازى

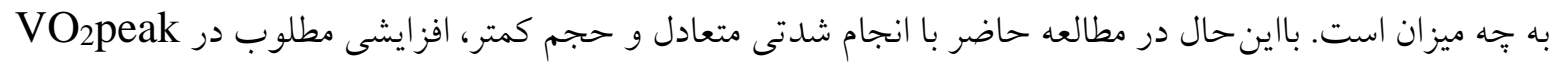

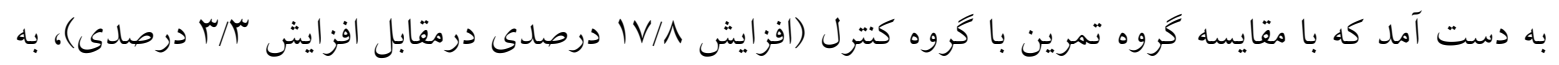
نظر مىرسد اين يروتكل HIT سهم بسيار زيادى در اين بيشرفت داشته است و با توجه به مطالعات HIT ديخر

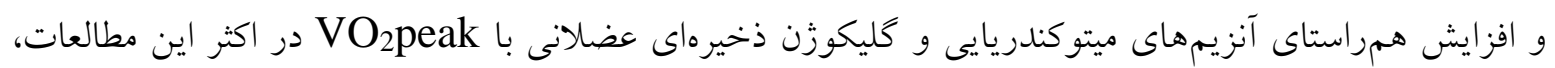
كه از عوامل بهبود ظرفيت هوازى تلقى مىشوند، معتقد هستيم كه در مطالعه حاضر نيز به احتمال زياد ميزان و بهخصوص فعاليت آنزيمهاى كليدى همجيون سيترات سينتاز و B-HAD نيز افزايش يافته است، ولى براى تأييد اين مدعا بهتر است مطالعات بيشترى انجام شود.

افزايش اكسيداسيون ¥ربى عضله اسكلتى، علاوهبر بهبود بيوزنز ميتوكندريايى و افزايش حجم ميتوكندرى (TQ)،

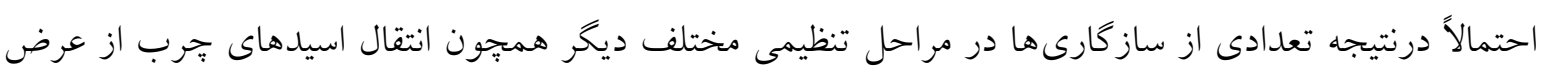
غشاهاى پِاسمايى و ميتو كندريايى است. ما بيان دو يروتئين انتقالى CD36 و FABPpm را در سطح ساركولما اندازه كيرى كرديم و معتقد بوديم كه مطالعه همزمان اين دو ناقل به جهت عملكرد هماهنگ آنها مطلوبتر است؛

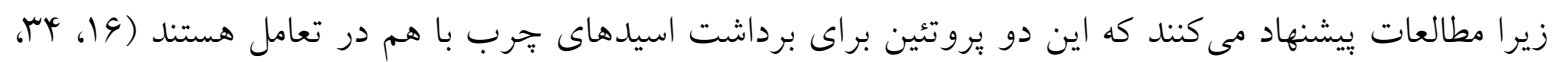

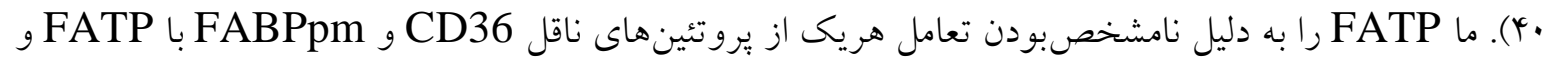
همجنين كمبود بافت عضلانى تحت ارزيابى قرار نداديم. علاوهبر اين، مطالعه FATP با محدوديتهاى بسيارى همجيون كيفيت پِيیين آنتىبادى براى عضله اسكلى انسانى همراه است (OS). از طرف ديخر، به جهت اهميت

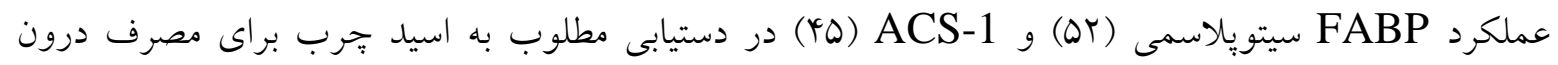
سلولى، يرداختن به تغييرات آنها دركنار يروتئينهاى غشايى ضرورت دارد. اما براساس مطالعات ديخران، به نظر مىرسد اين يروتئينها ظرفيت ساز گاريذيرى بسيار بايينى دارند (ه، ^ץ). لذا به نظر مى رسد مطالعه دو ناقل FABPpm و در روند انتقال اسيد جرب مى تواند بيانكر مطلوبى از فرآيند انتقال به درونسلول عضلانى باشد. بنابراين، فرضيات ما درجهت تغييرات ظرفيت انتقال و اكسيداسيون عضلات اسكلتى براساس تغييرات

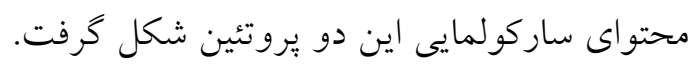

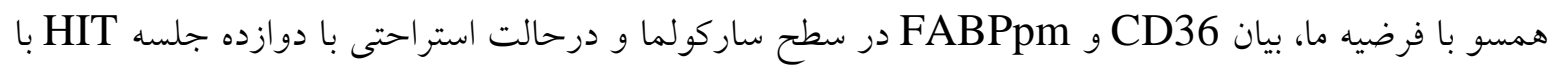

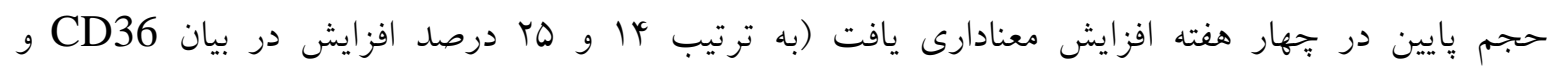

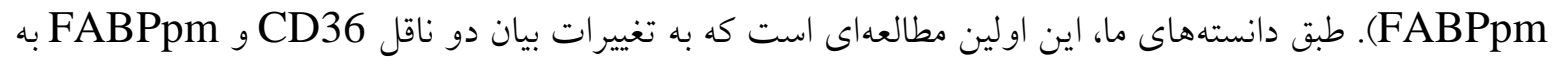
طور همزمان در سطح ساركولما در اثر يك دوره تمرين تناوبى شديد با حجم پايين برداخته و افزايش معنادار را

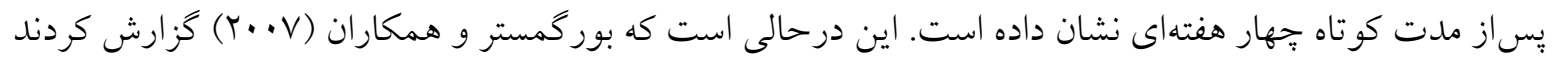




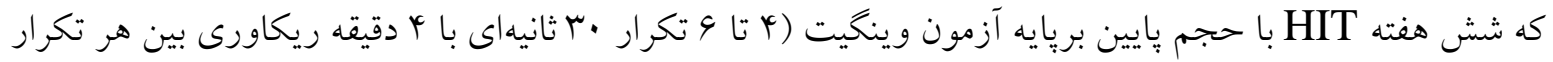
و سه جلسه در هفته) و شش هفته بى تمرينى به دنبال آن، تأثير معنادارى بر محتواى CD36 و FABPpm عضلانى ندارد (9). همجنين تالانيان و همكاران (Y..V) فقط افزايش معنادارى در محتواى FABPpm عضله

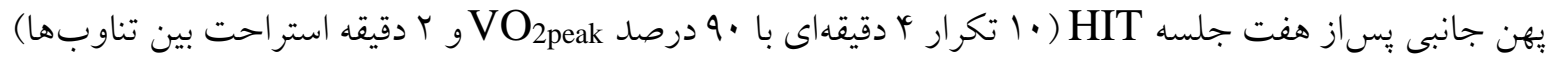

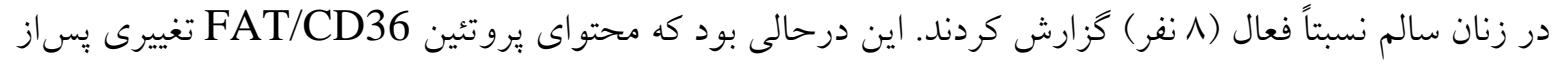
دوره تمرين نداشت (هD). تالانيان و همكاران در مطالعهاى مشابه (·. •(Y)، اينكه افزايش معنادار محتواى كلى يروتئينهاى CD36 و FABPpm را در عضله اسكلتى و در مدت دو و شش هفته HIT كزارش كردند، در سطح ساركولما اين افزايش را فقط در محتواى FABPpm معنادار يافتند (هو). اين افزايش را در درجه اول مى توان به آزمودنى هاى يزووهش و سطح آمادكى اوليه آنها مرتبط دانست. افرادى كه در مطالعات قبلى شركت كرده بودند بهصورت تفريحى ورزش مىكردند يا افراد تمرين كرده بودند كه از لحاظ توان هوازى و بىهوازى (حتى آزمودنى هاى زن) از آزمودنى هاى يزٔوهش حاضر در سطح بالاترى قرار داشتند. همجنين آزمودنى هاى ما اينكه در كلاس هاى ورزشى حضور بيدا مى كردند (مانند شنا، بدمينتون، كشتى)، هيجيك در رشته دوجرخهسوارى و حتى رشتهاى مشابه آن، كه بيشتر عضلات يايين تنه دركير كند، فعاليت نداشتند. از طرفى، جون تمرينهاى ورزشى ايشان

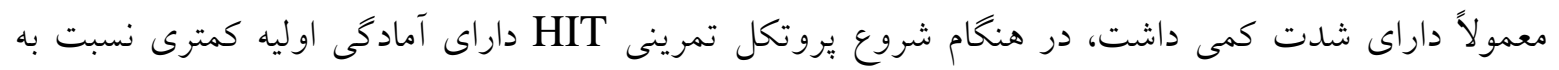
مطالعات ديخر بودند. البته بايستى تفاوتهاى زنتيكى را نيز در نظر گرفت، جر اكه اكثر مطالعات قبلى به امريكاى شمالى مربوط است و درباره نزاد بارسى 'اطلاعات مشابهى دردسترس نيست و اين اولين مطالعهاى بود كه درباره عضله انسان سالم و درقالب طرح تحقيقاتى ورزشى در ايران صورت گرفت. بههرحال ساز كارى بهدستآمده در

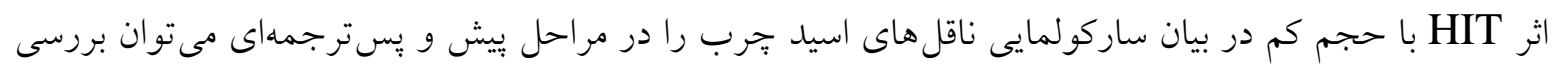

مىتوان فرض كرد كه يروتكل HIT حاضر بر فر آيندهاى بيشترجمهاى ناقلهاى اسيد جرب تأثير گذار بوده و موجب افزايش بيان mRNA و به دنبال آن افزايش بيان يروتئينى CD36 و FABPpm شده است. اخرجهه نمى توان احتمال تغيير در مراحل بيشترجمهاى را ناديده گرفت و آن را بر تغييرات بيان ساركولمايى ناقل هاى اسيد جرب بى تأثير دانست، با اين حال تغييرات در mRNA را نمىتوان از دلايل اصلى اين سازگارى به شمار آورد؛ جر اكه فرض معمول مبنى بر اينكه mRNAهاى ناقل اسيد خرب شاخص مناسبى از حاصل يروتئينى شان هستند مشكل زا و قابل بحث است. به طور مثال، تغييرات در mRNA هاى ناقل اسيد جرب غالبا با تغييرات در بيان

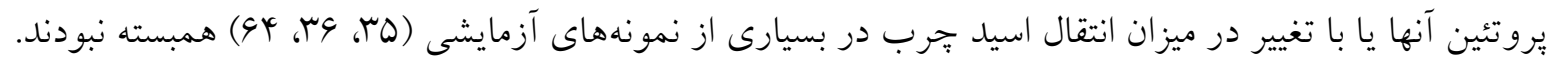
اين مسئله بيانكر نقشى اساسى براى فرآيندهاى يساز رونويسى است. سازگارى بِ ترجمهاى را نيز مىتوان از دو 


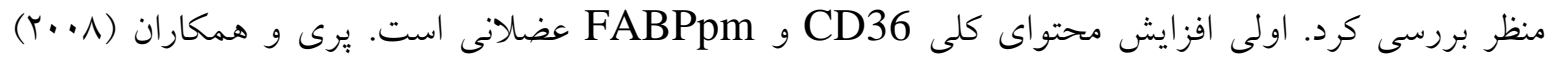

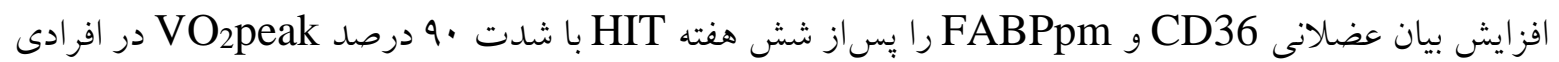
(r زن و ه مرد) كه به صورت تفريحى ورزش مى كردند گزارش كردند. در آن يزوهش ناقلهاى اسيد جرب در

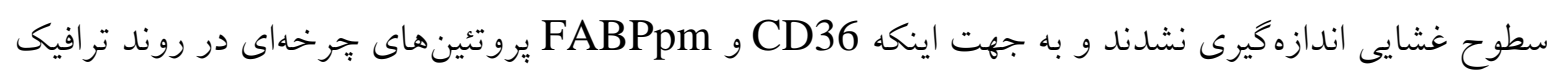
درونسلولى شناختهشدهاند، افزايش محتواى كلى CD36 و FABPpm را از دلايل اصلى افزايش روند

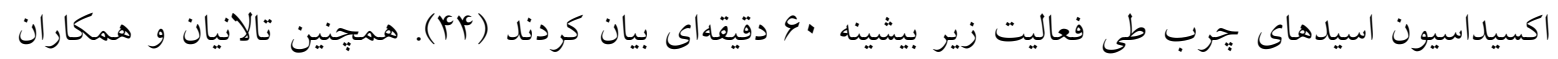

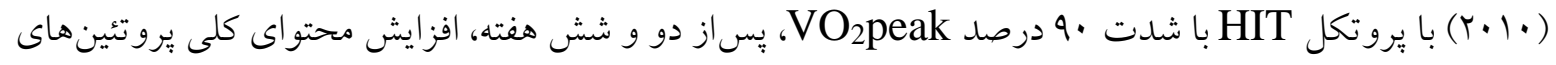

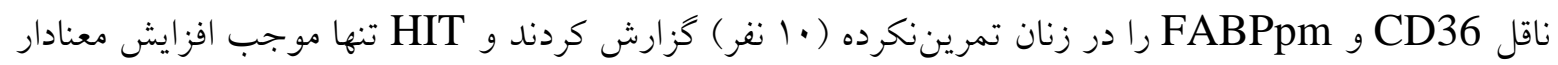
در بيان FABPpm ساركولمايى استراحتى شد (D9).

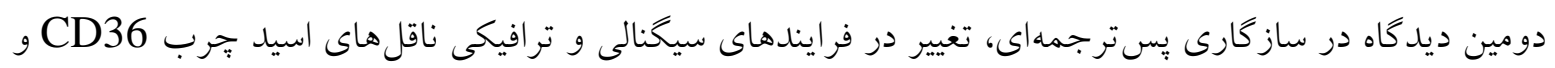
FABPpm

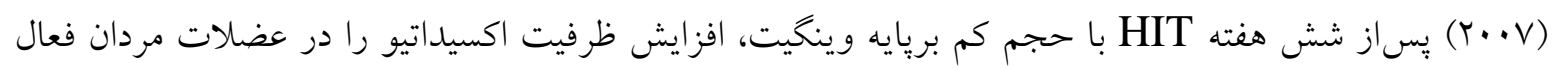
كزارش كردند، درحالى كه در محتو اى كلى ناقلهاى CD36 و FABPpm تغييرى مشاهده نشد، كه به نظر مىرسد به دليل جرخهاىبودن بروتئينهاى CD36 و FABPpm، اين افزايش به دليل بهبود روند انتقال اين ناقلها به سطح غشا در حين فعاليت بدنى يساز دوره تمرين باشد (9). مطالعات در ردههاى سلولى، ازطريق نشانداركردن سطح سلولى تأييد كرده است كه جابهجايى CD36 فرايندى سريع و بركشتيذير است (•) •و). كمان مىرود كه

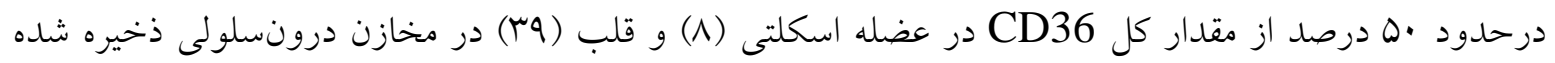
است. اين انبار داخل سلولى CD36 در بخش درونسلولى غنىشدهاى يافت شدند كه حاوى GLUT4 و كيرنده ترانسفرين (يروتئين اندوزومى) بود (9)؛ ازاينرو، همانند GLUT4، به نظر مىرسد CD36 بين اندوزومها و ساركولما درحال كردش است. در مطالعات ديخر نيز افزايش فعاليت عضله با تمرين ورزشى (DN) و تحريك هفت روزه عصب ناحيه خارجى ساق يا با بسامد كم (V، الM) موجب افزايش محتو اي ساركولمايى CD36 و FABPpm

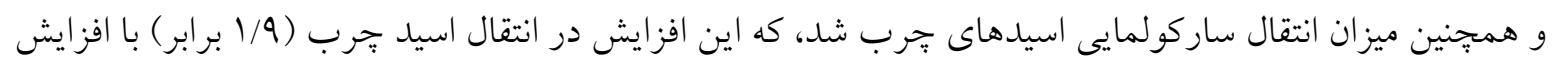
در متابوليسم اسيدهاى :جرب برابرى داشت (1/9 برابر، مقدار اكسايش و استرى كردن) (V). هم:نين القاى عدم فعاليت عضلانى (عصب بردارى هفت روزه)، ميزان انتقال اسيد جرب را كاهش داد و اين به دليل كاهش در CD36 و ساركولمايى بود. اين درحالى است كه در سطوح بيان مجموع بروتئين تغييرى وجود نداشت ( آس) و به طور كلى تنظيم مثبت و منفى در انتقال اسيد خرب در عضله به ميزان زيادى با محتو ایى ساركولمايى CD36 و FABPpm همبستخى داشت ( آس)؛؛ بنابراين، درواقع منبع عملكردى ناقل هاى اسيد جرب بـ آنهايى هستند كه در غشاى پِلاسمايى قرار دارند. 
در مطالعه حاضر نيز با اينكه جهار هفته HIT با حجم كم موجب افزايش معنادار در محتواى ساركولمايى CD36 و FABPpm درحالت استر احتى شد، مطابقتى بين افزايش اكسيداسيون اسيدهاى جرب بر درحين فعاليت زيربيشينه

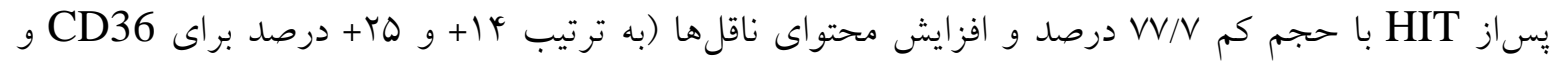

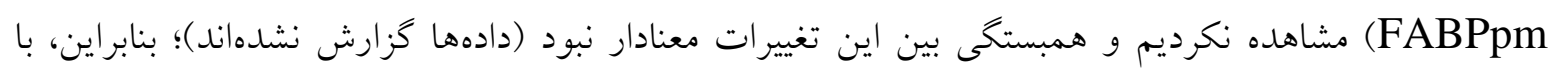
جمعبندى مطالعات (9) و نتايج كسبشده، معتقد هستيم كه در مطالعه حاضر، علاوهبر افزايش بيان كلى و ساركولمايى ناقل هاى اسيد جرب در زمان استراحت، HIT افزايش قوى ترى در روند جابهجايى اين ناقل ها درحين فعاليت بدنى ايجاد كرده است.

ازلحاظ مفهومى، رويدادهاى تنظيمى جابهجايى خالص يك يروتئين جرخهاى همانند CD36 مى تواند به ()

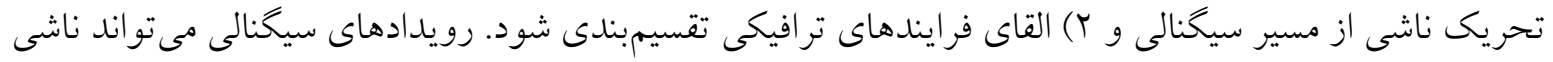

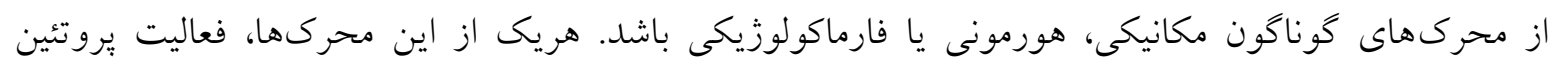

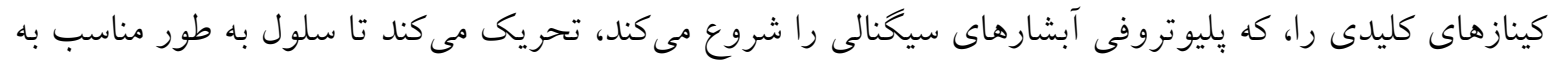

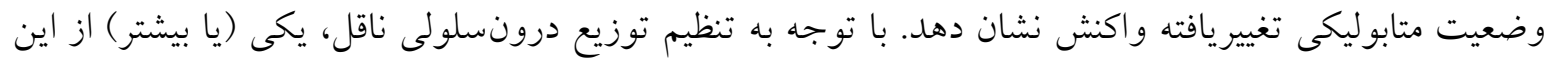

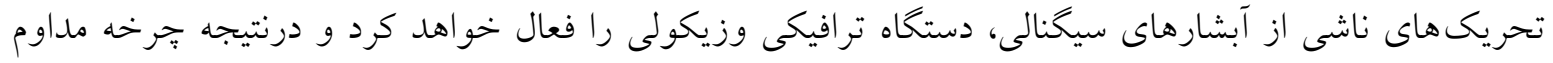

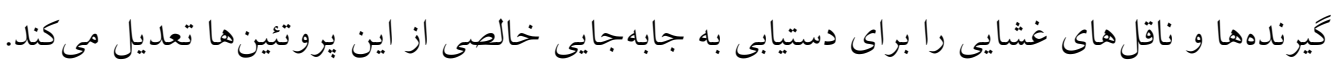

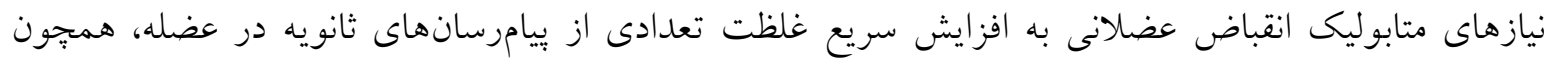

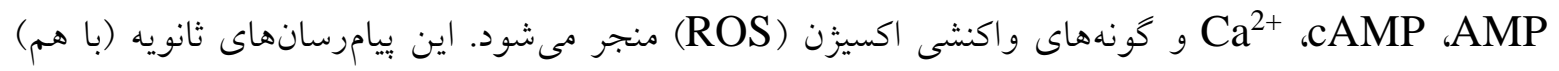
شبكهاى يبيجيده از رويدادهاى سيخنالى را فعال مى كنند (19). از ميان تمام بروتئين كينازهاى فعالشده ازطريق

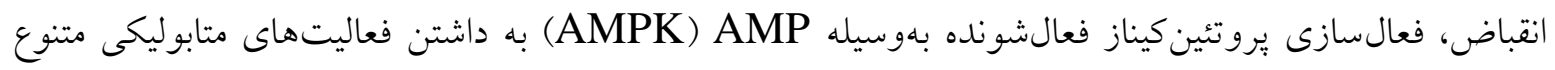

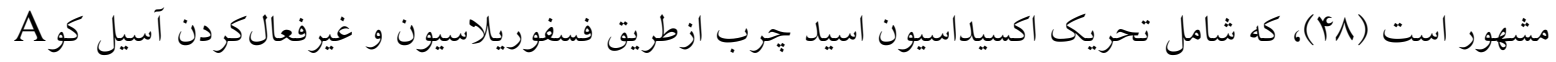

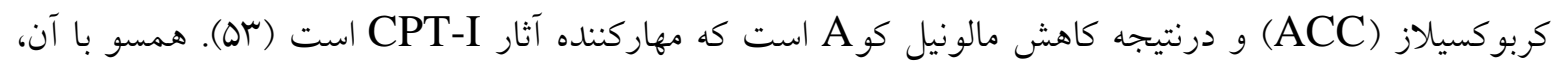
AMPK

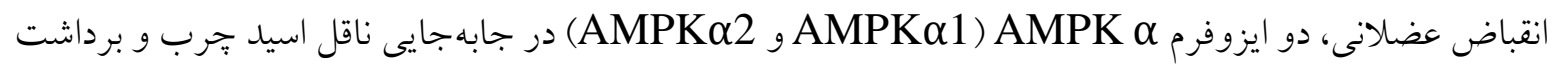

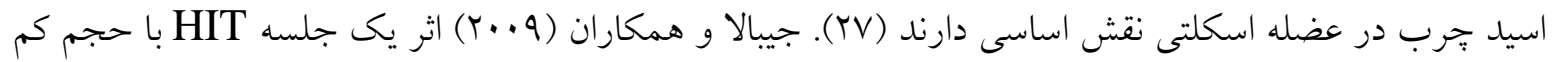

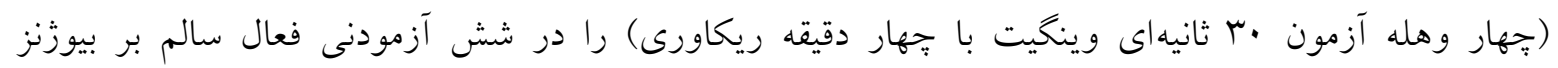
ميتو كندريايى بررسى كردند. درنتيجه يك جلسه تمرين تناوبى با شدت زياد و حجم كم، فسفوريلاسيون AMPK

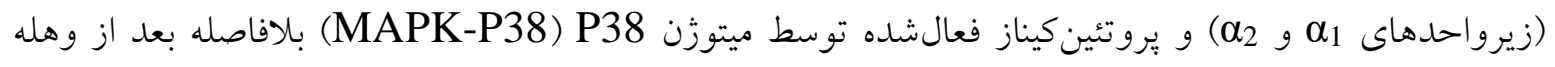

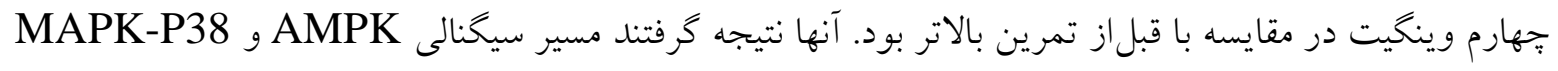


درجهت PGC-1 ممكن است توضيحدهنده قسمتى از تغييرات متابوليكى ناشى از HIT با حجم كم باشد كه شامل بيوزنز ميتو كندريايى و افزايش ظرفيت اكسيداسيون جربى و كلوكز است ( •ه). همجنين بايستى مسيرهاى فرادست AMPK را كه شامل AMPKK است نيز مورد توجه قرار داد. مطالعات

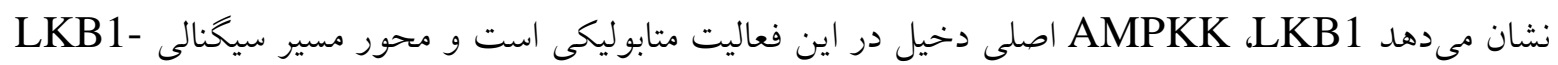

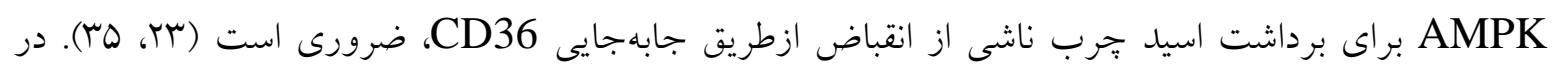
عضله اسكلتى، تنظيم برداشت اسيد جرب ناشى از انقباض ممكن است ازطريق فعالسازى CaMKK وابسته به AMPK و Ca Ca $^{2+}$ جرب مى شوند مشخص نشده است. درباب مسير سيخنالى انقباض فرودست AMPK نيز به نظر مىرسد كه AS160 نقطه تلاقى مسيرهاى سيخنالى انسولين و انقباض است، جايى كه روند ترافيك براى جابهجايى همزمان

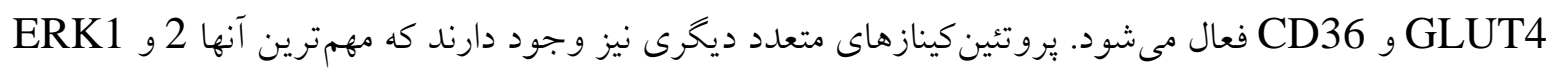
و ك - Pستند. يبشنهاد شده است كه ERK در جابهجايى CD36 و برداشت اسيد جرب ناشى از انقباض در عضله اسكلتى دخالت دارد (FV) و بخشى از برداشت اسيد جِرب ناشى از انقباض ممكن است ازطريق فعالسازى

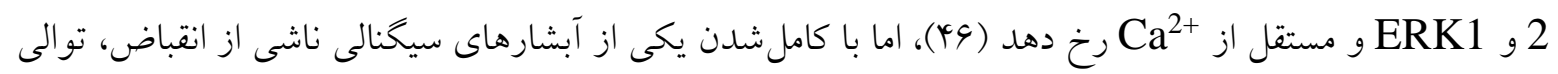

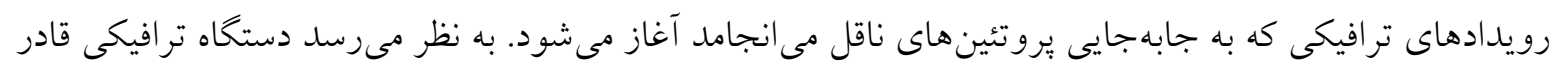

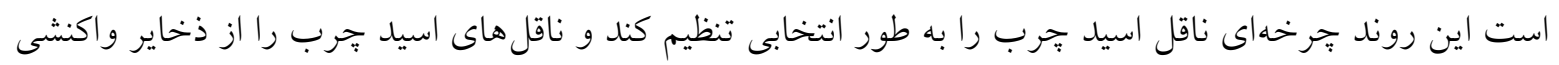

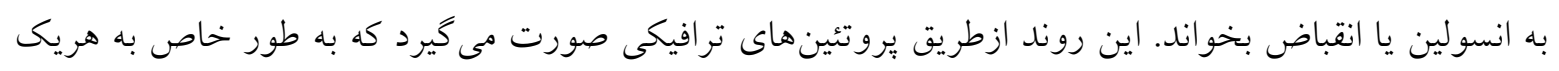

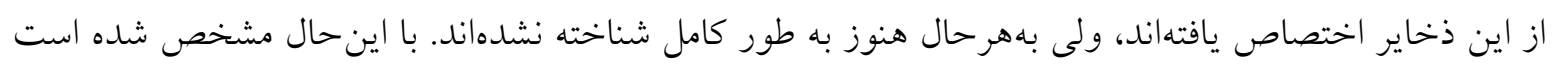
كه يروتئين آدايتور جانبى Munc18c كه عضوى از خانو اده Seclp-link/Munc18 است (•r) و و بروتئين يوششى كاوولين-r كه با CD36 در ساركولما در يك جايخاه استقرار دارد (9ז، اع) از يروتئينهاى ترافيكى

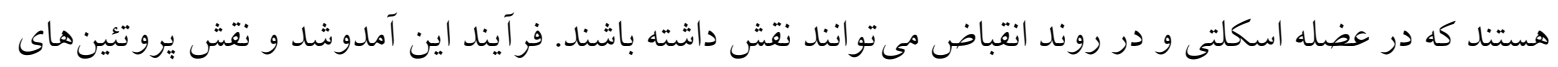
مزبور به طور كامل مشخص نشده است. با اين تفاسير، روشن است كه درحال حاضر ميزان اطلاعات درباره

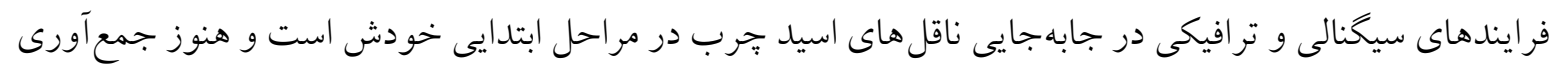
اطلاعات بيشتر درباره اين رويدادها لازم است.

\section{نتيجه}

به طور خلاصه، نتايج يزوهش حاضر نشان داد كه يروتكل HIT با حجم كم به كار رفته در مطالعه حاضر، كه نسبت

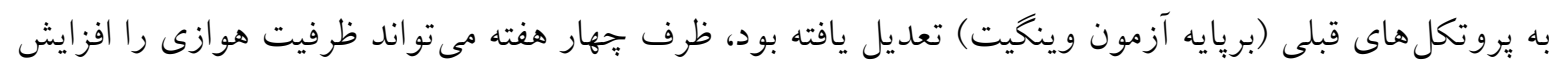

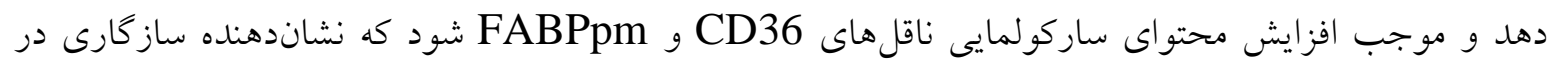
تسهيل انتقال اسيد جرب به درون عضله اسكلتى در جهت افزايش ظرفيت اكسيداسيون جربى است. هر جند به نظر 


$$
\begin{aligned}
& \text { مىرسد مطالعات بيشترى درباره يروتئينهاى درگير در مسيرهاى فرادست و فرودست اين ساز گارى بايد انجام } \\
& \text { شود تا افزايش ظرفيت اكسيداسيون جربى عضلانى در اثر اين نوع تمرين و هميجنين آشكارسازى فرايندهاى } \\
& \text { سيخنالى و ترافيكى، بـ تأييد برسد } \\
& \text { منابع }
\end{aligned}
$$

1. Abumrad, N., Coburn, C., Ibrahimi, A. (1999). Membrane proteins implicated inlong-chain fatty acid uptake by mammalian cells CD36,FATP and FABPm. Biochimica et Biophysica Acta. 1441(1):4-13.

2. Abumrad, N.A., el-Maghrabi, M.R., Amri, E.Z., Lopez, E., Grimaldi, P.A. (1993). Cloning of a rat adipocyte membrane protein implicated in binding or transport of long chain fatty acids that is induced during prea- dipocyte differentiation. Homology with human CD36. The Journal of Biological Chemistry.

268(24):17665-8.

3. Bartlett, J.D., Close, G.L., MacLaren, D.P., Warren, G., Barry, D., James, P. (2011). High-intensity interval running is perceived to be more enjoyable than moderate-intensity continuous exercise: Implications for exercise adherence. Journal of Sports Sciences. 29(6):547-53.

4. Babraj, J.A., Vollaard, N.B., Keast, C., Guppy, F.M., Cottrell, G., Timmons, J.A.(2009). Extremely short duration high intensity interval training substantially improves insulin action in young healthy males. BMC Endocrine Disorders. 9:3.

5. Binas, B., Han, X.X., Eroll, E., Luiken, J.J., Glatz, J.F., Dyck, D.J., Motazavi, R., Adihetty, P.J., Hood, D.A., Bonen, A. (2003). A null mutation in H-FABP only partially inhibits skeletal muscle fatty acid metabolism. American Journal of Physiology Endocrinology and Metabolism. 285: E481-E489., .

6. Bonen, A., Campbell, S.E., Benton, C.R., Chabowski, A., Coort, S.L., Han, X.X., Koonen, D.P., Glatz, J.F., Luiken, J.J. (2004). Regulation of fatty acid transport by fatty acid translocase/CD36. Proceedings of the Nutrition Society. 63: 245-9.

7. Bonen, A., Dyck, D.J., Ibrahimi, A., Abumrad, N.A. (1999). Muscle contrac- tile activity increases fatty acid metabolism and transport and FAT/CD36. American Journal of Physiology - Endocrinology and Metabolism. 276: E642-E649.

8. Bonen, A., Luiken, J.J., Arumugam, Y., Glatz, J.F.C., Tandon, N.N. (2000). Acute regulation of fatty acid uptake involves the cellular redistribution of fatty acid translocase. The Journal of Biological Chemistry. 275: 14501-8.

9. Burgomaster Kirsten, A., Burgomaster, K.A., Naomi, M., Cermak, N.M., Stuart, M., Phillips, S.M., Carley, R., Benton, C.R., Bonen, A., Martin, J., Gibala, M.J.. (2007). Divergent response of metabolite transport proteins in human skeletal muscle after sprint interval training and detraining. American Journal of Physiology - Regulatory, Integrative and Comparative Physiology. 292(5): R1970-R6.

10. Burgomaster, K.A., Heigenhauser, G.J., Gibala, M.J. (2006). Effect of short-term sprint interval training on human skeletal muscle carbohydrate metabolism during exercise and time-trial performance. Journal of Applied Physiology. 100(6): 2041-7. 11. Burgomaster, K.A., Hughes ,S.C., Heigenhauser, G.J., Bradwell, S.N., Gibala, M.J.(2005). Six sessions of sprint interval training increases muscle oxidative potential and cycle endurance capacity in humans. Journal of Applied Physiology. 98(6): 1985-90.

12. Burgomaster, K.A., Howarth, K.R., Phillips, S.M., Rakobowchuk, M., Macdonald, M.J., McGee, S.L .,

Gibala, M.J.(2008). Similar metabolic adaptations during exercise after low volume sprint interval and traditional endurance training in humans. The Journal of Physiology. 586(1): 151-60.

13. Butz, C.E., McClelland, G.B., Brooks, G.A. (2004). MCT1 confirmed in rat striated muscle mitochondria. Journal of Applied Physiology. 97(3): 1059-66.

14. Carter, S.L., Rennie, C.D., Hamilton, S.J., Tarnopolsky, M.A. (2001). Changes in skeletal muscle in males and females following endurance training. Canadian Journal of Physiology and Pharmacology. 79(5): 386-92.

15. Chabowski, A., Coort, S.L., Calles-Escandon, J., Tandon, N.N., Glatz, J.F., Luiken, J.J., Bonen, A. (2005). The subcellular compartmentation of fatty acid transporters is regulated differently by insulin and by AICAR. FEBS Lett. 579(11): 2428-32.

16. Chabowski, A., Gorski, J., Luiken, J.J., Glatz ,J.F., Bonen, A.(2007). Evidence for concerted action of FAT/CD36 and FABPpm to increase fatty acid transport across the plasma membrane. Prostaglandins Leukot Essent Fatty Acids 77(5-6): 345-53.

17. Coburn, C.T., Knapp, F.F., Febbraio, M., Beets, A.L., Silverstein, R.L., Abumrad, N.A. (2000). Defective uptake and utilization of long chain fatty acids in muscle and adipose tissue of CD36 knockout mice. The Journal of Biological Chemistry. 275(42): 32523-9.

18. Eyre, N.S., Cleland, L.G., Mayrhofer, G. (2008). FAT/CD36 expression alone is insufficient to enhance cellular uptake of oleate. Biochemical and Biophysical Research Communications. 370: 404-9.

19. Gibala, M.J., Little, J.P., van Essen, M., Wilkin, G.P., Burgomaster, K.A., Safdar, A., Raha, S ., Tarnopolsky ,M.A. (2006). Short-term sprint interval versus traditional endurance training: similar initial adaptations in human skeletal muscle and exercise performance. The Journal of Physiology. 575: 901-11.

20. Gibala, M.J., Little, J.P., MacDonald, M.J., Hawley, J.A. (2012). Physiological adaptations to low-volume, high-intensity interval training in health and disease. The Journal of Physiology. 590(5): 1077-84.

21. Gimeno, R.E., Ortegon, A.M., Patel, S., Punreddy, S., Ge, P., Sun, Y., Lodish, H.F., Stahl, A.(2013). Characterization of a heart-specific fatty acid transport protein. The Journal of Biological Chemistry. 278(18): 16039-44.

22. Goodpaster, B.H., Katsiaras, A., Kelley, D.E. (2003). Enhanced fat oxidation through physical activity is associated with improvements in insulin sensitivity in obesity. Diabetes. 52: 2191-7.

23. Habets, D.D.J. (2008). Regulation of cardiac longchain fatty acid and glucose metabolism: studies with cardiomyocytes from genetically manipulated mice (PhD thesis). Maastricht: Maastricht University 
24. Hajri, T., Abumrad, N.A. (2002). Fatty acid transport across membranes: relevance to nutrition and metabolic pathology. Annual Review of Nutrition. 22: 383-415.

25. Holloszy, J.O., Booth, .F.W. (1976). Biochemical adaptations to endurance exercise in muscle. Annual Review of Physiology. 38: 273-91.

26. Isola, L.M., Zhou, S.L., Kiang, C.L., Stump, D.D., Bradbury, M.W., Berk, P.D. (1995). 3T3 fibroblasts transfected with a cDNA for mitochondrial aspartate aminotransferase express plasma membrane fatty acid- binding protein and saturable fatty acid uptake. Proceedings of the National Academy of Sciences USA 92: 9866-70.

27. Jørgensen, S.B., Viollet, B., Andreelli, F., Frosig, C., Birk, J.B., Schjerling, P., Vaulont, S., Richter, E.A., Wojtaszewski, J.F. (2004). Knock out of the alpha2 but not alpha1 5-AMP-activated protein kinase isoform abolishes 5-aminoimidazole-4carboxamide-1-beta-4-ribo- furanoside but not contraction-induced glucose uptake in skeletal muscle. The Journal of Biological Chemistry. 279: 1070-9.

28. Kampf, J.P., Kleinfeld, A.M. (2007). Is membrane transport of FFA mediated by lipid, protein, or both? An unknown protein mediates free fatty acid transport across the adipocyte plasma membrane. Physiology 22: 7-14.

29. Keizer, H.A., Schaart, G., Tandon, N.N., Glatz, J.F., Luiken, J.J. (2004). Subcellular immunolocalisation of fatty acid translocase (FAT)/CD36 in human type-1 and type-2 skeletal muscle fibres. Histochemistry and Cell Biology. 121: 101-7. 30. King, A.C., Haskell, W.L., Young, D.R., Oka, R.K., Stefanick, M.L. (1995). Long-term effects of varying intensities and formats of physical activity on participation rates, fitness, and lipoproteins in men and women aged 50 to 65 years. Circulation. 91(10): 2596-604.

31. Koonen, D.P.Y., Benton ,C.R., Arumugam, Y., Tandon, N.N., Calles, E.J., Glatz, J.F.C, Luiken, J.J., Bonen, A. (2004). Different mechanisms can alter fatty acid transport when muscle contractile activity is chronically altered. American Journal of Physiology - Endocrinology and Metabolism. 286: 1042-9.

32. Laursen, P.B., Shing, C.M., Peake, J.M., Coombes, J.S., Jenkinse, D.G. (2005). Influence of high-intensity interval training on adaptations in well-trained cyclists. The Journal of Strength \& Conditioning Research. 19(3): 527-33.

33. Little, J.P., Safdar, A., Wilkin, G.P., Tarnopolsky, M.A., Gibala, M.J. (2010). A practical model of low-volume high-intensity interval training induces mitochondrial biogenesis in human skeletal muscle: potential mechanisms. The Journal of Physiology. 588(6): 1011-22.

34. Luiken, J.J., Arumugam, Y., Bell, R.C, Calles-Escandon, J., Tandon, N.N., Glatz, J.F., Bonen, A. (2002). Changes in fatty acid transport and transporters are related to the severity of insulin deficiency. American Journal of Physiology - Endocrinology and Metabolism. 283(3): 612-21.

35. Luiken, J.J., Coort, S.L., Willems, J., Coumans, W.A., Bonen, A., van der Vusse, G.J., Glatz, J.F. (2003). Contractioninduced fatty acid translocase/CD36 translocation in rat cardiac myocytes is mediated through AMP-activated protein kinase signaling. Diabetes 52(7): 1627-34.

36. Luiken, J.J., Dyck, D.J., Han, X.X., Tandon, N.N., Arumugam ,Y., Glatz, J.F, Bonen, A. (2002). Insulin induces the translocation of the fatty acid transporter FAT/CD36 to the plasma membrane. American Journal of Physiology - Endocrinology and Metabolism. 282(2): 491-5.

37. Luiken, J.J., Han, X.X., Dyck, D.J., Bonen, A. (2001). Coordinately regu- lated expression of FAT/CD36 and FACS1 in rat skeletal muscle. Molecular and Cellular Biochemistry. 223: 61-9.

38. Luiken, J.J.F.P., Koonen, D.P.Y., Coumans ,W.A., Pelsers, M.M.A.L., Binas, B., Bonen, A., Glatz, J.F.C. (2003).Long chain fatty acid uptake by skeletal muscles is impaired in homozygous, but not heterozygous, heart-type--FABP null mice. Lipids 38(4): 491-6.

39. Luiken, J.J.F.P., Koonen, D.P.Y., Willems, J., Zorzano, A., Fischer, Y., van der Vusse, G.J., Bonen, A., Glatz, J.F.C. (2002) Insulin stimulates longchain fatty acid uilization by rat cardiac myocytes through cellular redistribution of FAT/CD36. Diabetes. 51: 3113-19.

40. Luiken, J.J.F.P., Turcotte, L.P., Bonen, A. (1999). Protein-mediated palmitate uptake and expression of fatty acid transport proteins in heart giant vesicles. The Journal of Lipid Research. 40: 1007-16.

41. Luiken, J.J.F.P., Willems, J., Coort, S.L., Coumans, W.A., Bonen, A., van der Vusse, G,J., Glatz, J.F.C. (2002). Effects of CAMP modulators on long-chain fatty-acid uptake and utilization by electrically stimulated rat cardiac myocytes. Biochemical Journal. 367: 881-8.

42. Nickerson, J.G., Alkhateeb, H., Benton, C.R., Lally, J., Nickerson, J., Han, X.X., Wilson, M.H., Jain, S.S., Snook, L.A., Glatz, J.F.C., Chabowski, A., Luiken, J.J.F.P., Bonen, A. (2009). Greater transport efficiencies of the membrane fatty acid transporters FAT/CD36 and FATP4 compared with FABPpm and FATP1: differential effects on fatty acid esterification and oxidation in rat skeletal muscle. The Journal of Biological Chemistry. 284: 16522-30.

43. Palanivel, R., Sweeney, G. (2005). Regulation of fatty acid uptake and metabolism in L6 skeletal muscle cells by resistin. FEBS Letters. 579: 5049-54.

44. Perry, C.G.R., Heigenhauser, G.J.F., Bonen, A., Spriet, L.L. (2008). High-intensity aerobic interval training increases fat and carbohydrate metabolic capacities in human skeletal muscle. Applied Physiology, Nutrition, and Metabolism. 33: 1112-23. 45. Rabol, R., Boushel, R., Dela, F. (2006). Mitochondrial oxidative function and type 2 diabetes. Applied Physiology, Nutrition, and Metabolism. 31: 675-83.

46. Raney, M.A., Turcotte, L.P. (2008). Evidence for the involvement of CaMKII and AMPK in Ca2-dependent signaling pathways regulating FA uptake and oxidation in contracting rodent muscle. Journal of Applied Physiology. 104: 1366-73.

47. Raney, M.A., Yee, A.J., Todd, M.K., Turcotte, .L.P. (2005). AMPK activation is not critical in the regulation of muscle FA uptake and oxidation during low-intensity muscle contraction. American Journal of Physiology - Endocrinology and Metabolism. 288: $592-8$.

48. Richter, E.A., Nielsen, J.N., Jørgensen, S.B., Frosig, C., Birk, J.B., Wojtaszewski, J.F. (2004). Exercise signalling to glucose transport in skel- etal muscle. Proceedings of the Nutrition Society. 63: 211-6.

49. Richter, E.A., Nielsen, J.N., Jørgensen, S.B., Frosig, C., Wojtasze- wski, J.F. (2003). Signalling to glucose transport in skeletal muscle during exercise. Acta Physiol Scand. 178: 329-35. 
50 . Little, J.P., Safdar, A., Bishop, D., Tarnopolsky, M.A., Gibala, M.J. (2011). An acute bout of high-intensity interval training increases the nuclear abundance of PGC-1 $\alpha$ and activates mitochondrial biogenesis in human skeletal muscle. American Journal of Physiology Regulatory Integrative and Comparative Physiology. 300(6): 1303-10

51. Rognmo, O., Hetland, E., Helgerud, J., Hoff, J., Slordahl, S.A. (2004). High intensity aerobic interval exercise is superior to moderate intensity exercise for increasing aerobic capacity in patients with coronary artery disease. European journal of cardiovascular prevention and rehabilitation. 11(3): 216-22.

52. St-Denis, J.F., Cushman, S.W. (1998). Role of SNARE's in the GLUT4 translocation response to insulin in adipose cells and muscle. Journal of Basic and Clinical Physiology and Pharmacology. 9: 153-65.

53. Stanley, W.C., Recchia, F.A., Lopaschuk, G.D. (2005). Myocardial substrate metabolism in the normal and failing heart. Physiological Reviews. 85: 1093-129.

54. Susan, L.M., Bonen, A., Vusse,G.L. (2007). Cardiac substrate uptake and metabolism in obesity and type-2 diabetes: Role of sarcolemmal substrate transporters. Molecular and Cellular Biochemistry. 299: 5-18.

55. Talanian, J.L., Galloway, S.D., Heigenhauser ,G.J., Bonen, A., Spriet, L.L. (2007). Two weeks of high-intensity aerobic interval training increases the capacity for fat oxidation during exercise in women. Journal of Applied Physiology. 102: 14391447

56. Talanian, J.L., Graham, P., Holloway, L.A., George, J.F., Bonen, A., Lawrence, L. (2010). Exercise training increases sarcolemmal and mitochondrial fatty acid transport proteins in human skeletal muscle. American Journal of Physiology Endocrinology and Metabolism. 299: 180-8.,.

57. Trost, S.G., Owen, N., Bauman, A.E., Sallis, J.F., Brown,W. (2002) Correlates of adults' participation in physical activity: review and update. Medicine \& Science in Sports \& Exercise. 34: 1996-2002.

58. Turcotte, L.P, Swenberger, J.R., Tucker, M.Z., Yee, A.J. (1999). Training induced elevation in FABPpm is associated with increased palmitate use in contracting muscle. Journal of Applied Physiology. 87: 285-93.

59. Van Loon, L.J. (2004). Use of intramuscular triacylglycerol as a substrate source during exercise in humans. Journal of Applied Physiology. 97(4): 1170-87.

60. Van Oort, M.M., van Doorn ,J.M., Bonen, A., Glatz, J.F., van der Horst, D.J., Rodenburg, K.W., Luiken, J.J. (2008). Insulininduced translocation of CD36 to the plasma membrane is reversible and shows similarity to that of GLUT4. Biochimica et Biophysica Acta. 1781(1-2): 61-71.

61. Vistisen, B., Roepstorff, K., Roepstorff, C., Bonen, A., van Deurs, B., Kiens, B. (2004). Sarcolemmal FAT/CD36 in human skeletal muscle colocalizes with caveolin-3 and is more abundant in type1 than type 2 fibers. The Journal of Lipid Research. 45: 603-9.

62. Warburton, D.E., McKenzie, D.C., Haykowsky, M.J., Taylor, A., Shoemaker, P., Ignaszewski, A.P., Chan, S.Y. (2005). Effectiveness of highintensity interval training for the rehabilitation of patients with coronary artery disease. American Journal of Cardiology. 95: 1080-4.

63. Whyte, L.J., Gill, J.M., Cathcart, A.J. (2010). Effect of 2 weeks of sprint interval training on health-related outcomes in sedentary overweight/obese men. Metabolism. 59: 1421-8.

64. Wu, Q., Ortegon ,A.M., Tsang, B., Doege, H., Feingold, K.R., Stahl, A. (2006). FATP1 is an insulin-sensitive fatty acid transporter involved in diet-induced obesity. Molecular and Cellular Biology. 26: 3455-67. 